Check for updates

Cite this: RSC Adv., 2021, 11, 25738

Received 25th May 2021

Accepted 23rd June 2021

DOI: $10.1039 / \mathrm{d} 1 \mathrm{ra0} 4061 \mathrm{~h}$

rsc.li/rsc-advances

\section{Structure-based design, synthesis, and biological evaluation of novel piperine-resveratrol hybrids as antiproliferative agents targeting SIRT-2 $\dagger$}

\author{
Ahmed H. Tantawy, (D)*abc Xiang-Gao Meng, ${ }^{\star d}$ Adel A. Marzouk, ${ }^{e}$ Ali Fouad, \\ Ahmed H. Abdelazeem, ${ }^{\text {fg }}$ Bahaa G. M. Youssif, (D) ${ }^{\mathrm{h}}$ Hong Jiang ${ }^{* \mathrm{~b}}$ \\ and Man-Qun Wang *a
}

A series of novel piperine-resveratrol hybrids $5 \mathrm{a}-\mathrm{h}$ was designed, synthesized, and structurally elucidated by $\mathrm{IR}$, and ${ }^{1} \mathrm{H},{ }^{13} \mathrm{C}$, and ${ }^{19} \mathrm{~F}$ NMR. Antiproliferative activities of $5 \mathrm{a}-\mathrm{h}$ were evaluated by $\mathrm{NCl}$ against sixty cancer cell lines. Compound $5 \mathrm{~b}$, possessing resveratrol pharmacophoric phenolic moieties, showed a complete cell death against leukemia HL-60 (TB) and Breast cancer MDA-MB-468 with growth inhibition percentage of -0.49 and -2.83 , respectively. In addition, $5 \mathrm{~b}$ recorded significant activity against the other cancer cell lines with growth inhibition percentage between 80 to 95 . New $5 a-h$ hybrids were evaluated for their inhibitory activities against Sirt-1 and Sirt-2 as molecular targets for their antiproliferative action. Results showed that compounds $5 \mathrm{a}-\mathrm{h}$ were more potent inhibitors of Sirt- 2 than Sirt-1 at $5 \mu \mathrm{m}$ and $50 \mu \mathrm{m}$. Compound $5 \mathrm{~b}$ showed the strongest inhibition of Sirt-2 $(78 \pm 3 \%$ and $26 \pm 3 \%$ inhibition at $50 \mu \mathrm{M}$ and $5 \mu \mathrm{M}$, respectively). Investigation of intermolecular interaction via Hirschfeld surface analysis indicates that these close contacts are mainly ascribed to the $\mathrm{O}-\mathrm{H} \cdots \mathrm{O}$ hydrogen bonding. To get insights into the Sirt- 2 inhibitory mechanism, a docking study was performed where $5 \mathrm{~b}$ was found to fit nicely inside both extended $\mathrm{C}$-pocket and selectivity pocket and could compete with the substrate acyl-Lys. Another possible binding pattern showed that $5 \mathrm{~b}$ could act by partial occlusion of the $\mathrm{NAD}^{+} \mathrm{C}$-pocket. Collectively, these findings would contribute significantly to better understanding the Sirt-2 inhibitory mechanism in order to develop a new generation of refined and selective Sirt-2 inhibitors.

\section{Introduction}

Since cancer is one of the world's leading major health problems causing death, ${ }^{\mathbf{1 - 3}}$ finding and discovering new successful anticancer drugs is one of the biggest challenges in drug research. Sirtuins have attracted attention over the last decade because they have participated in the regulation of many processes that affect cancer cells, ${ }^{4,5}$ such as cellular metabolism, ${ }^{6,7}$ chromatin structure control and genomic stability maintenance. ${ }^{8,9}$ Sirtuins are part of a family of seven human enzymes (SIRT1-7), which are NAD-related histone deacetylases (HDACs). ${ }^{10,11}$ With NAD, SIRTs catalyze acetyl group removal from $\mathrm{N}$-acetyl lysine amino acid on histone substrates which generates deacetylated proteins, nicotinamides and $O$-acetylADP-ribose molecules. ${ }^{12,13}$ Isotype Sirt-2 has taken part in several cellular processes such as gene transcription, genome constancies and cell cycle regulation during mitosis. ${ }^{\mathbf{1 4 , 1 5}}$ Sirt-2 is a key factor in the development of cancer and metastasis by increasing cancer cell motility. ${ }^{16}$ In addition, Sirt-2 inhibition showed an increase in tumor suppressor genes, including p53 and $221 .{ }^{17}$ Small molecules that can control sirtuin activities are therefore considered potential therapeutics for the treatment of 


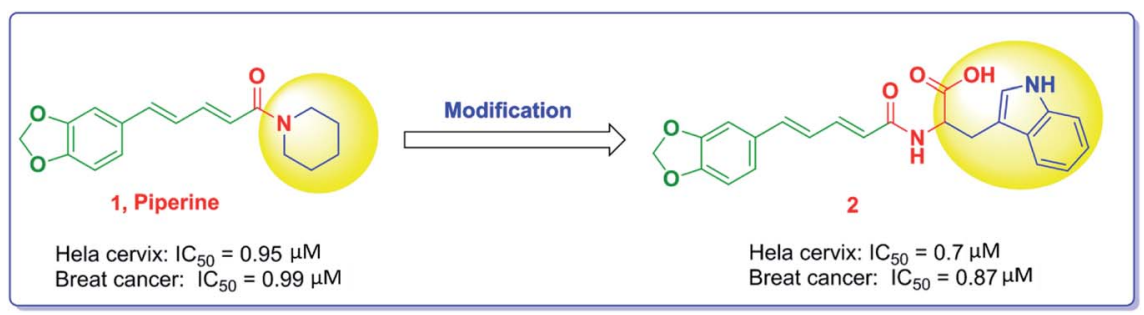

Fig. 1 The modification of piperine structure and the impact on the anticancer activity.

various human disorders, including cancer. Knockdown or inhibition of Sirt-2 may disrupt the metabolism of cancer cells and thus prevent the spread and growth of cancer cells. ${ }^{18-21}$

Natural products are one of the chief consistent sources of lead drugs. Developments based on natural products including various anticancer drugs such as topotecan, docetaxel, vindesine, etoposide and vinorelbine have been published..$^{22,23}$ Natural products produced from bacterial, fungal, marine, plant and animal sources and natural product-inspired compounds have wide benefits in clinical trials as antiinflammatory drugs, anticancer drugs, or other pharmaceutical agents. ${ }^{24}$ It is estimated that natural product-derived compounds constitute more than $50 \%$ of anticancer agents; about $74 \%$ of anticancer compounds are either natural or natural product-inspired compounds. ${ }^{25}$

Piperine, Fig. 1, is a nitrogenous alkaloid found in black pepper powder fruit that is widely used as a food flavor in a number of countries and used in many conventional food preservation systems as well as in traditional medicines. ${ }^{26}$ Piperine was proven to have anticancer activity with various mechanisms of action. The substitution of the piperidine moiety with bulkier and extended groups has been reported to significantly enhance the potency as noted in compound 2, where the tryptophanyl moiety has been added. ${ }^{22}$

On the other hand, the polyphenolic compounds such as resveratrol and piceatannol showed high affinity to the human sirtuins family with a great modulating potential. The wellknown stilbenoid polyphenol, resveratrol, was reported as a Sirt-1 and Sirt-5 activator while a weak Sirt-2 and Sirt-3 inhibitor. ${ }^{27-31}$ However, its metabolite piceatannol was found to act as an inhibitor to Sirt-2 protein. ${ }^{31}$ From the study of the reported SAR and the interactions with some SIRT proteins, it was conceptualized that the phenolic moieties have a remarkable impact on their SIRT activities. ${ }^{27-31}$ Till now, there are no reported studies addressing the binding pattern and the key interactions of resveratrol with Sirt-2 subtype despite the high degree of structural similarity between the conserved catalytic domains of the human sirtuins family. In order to explore this possible pattern and optimize its activity against Sirt-2 in particular, resveratrol was docked into the active site of Sirt-2 (pdb code: 4RMG) co-crystallized with the SirReal2 ligand using the Ligand Fit protocol found in Discovery Studio software 2.5. It was obvious from the docking results that resveratrol occupied a part of the extended C-site at the interface between the Rossmann-fold domain and the zinc-binding domain without any clashing with either the acyl-Lys substrate channel or the nicotinamide moiety of the co-factor $\mathrm{NAD}^{+}$. It was involved in only one conventional $\mathrm{H}$-bond with the Ile-118 residue and some hydrophobic interactions with Leu-134 Leu-138, Tyr-139, Phe-143, and Phe-190 amino acids. This interpretation suggests a considerable possibility for further structural optimization, Fig. 2(A and B). This point can

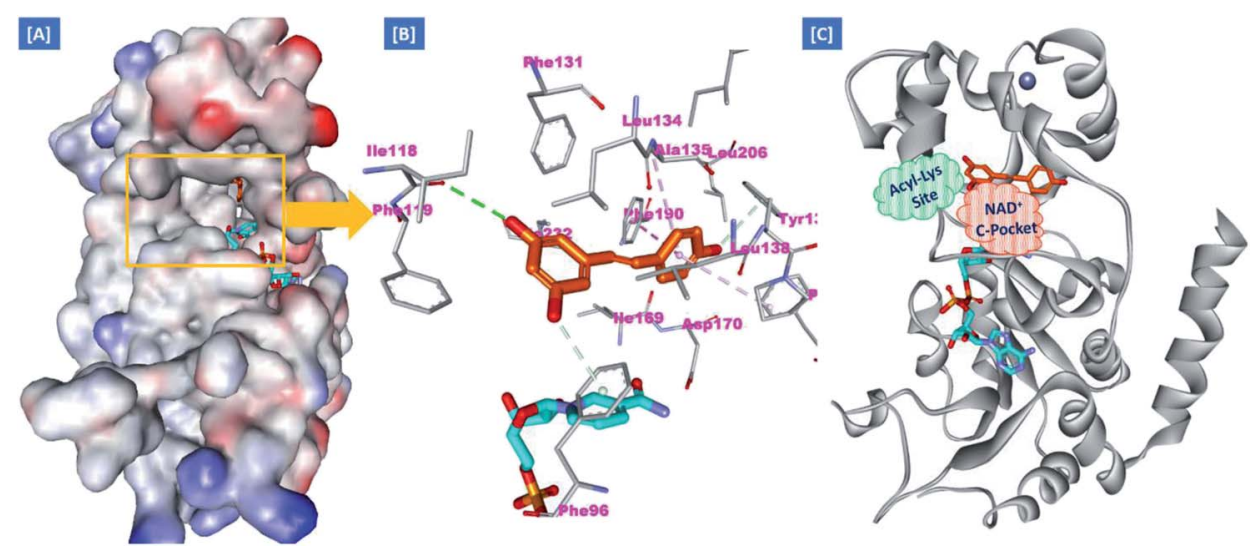

Fig. 2 Docking of resveratrol into SIRT-2 3D structure (pdb code: 4RMG). (A) The disposition of resveratrol (orange) inside SIRT-2 active site where the protein is represented as a solid surface colored according to atom charges; (B) the predicted binding pattern and interactions of resveratrol within the active site of SIRT-2; (C) the suggested sites of structural modifications and elongation of resveratrol; green mesh represents the Acyl-Lys substrate channel and the red mesh represents the C-pocket of nicotinamide moiety of $\mathrm{NAD}^{+} \mathrm{co}-\mathrm{factor}$ (cyan). The poses were rendered as stick model and the residues are shown as smaller grey sticks. All hydrogens were removed for the purposes of clarity. 


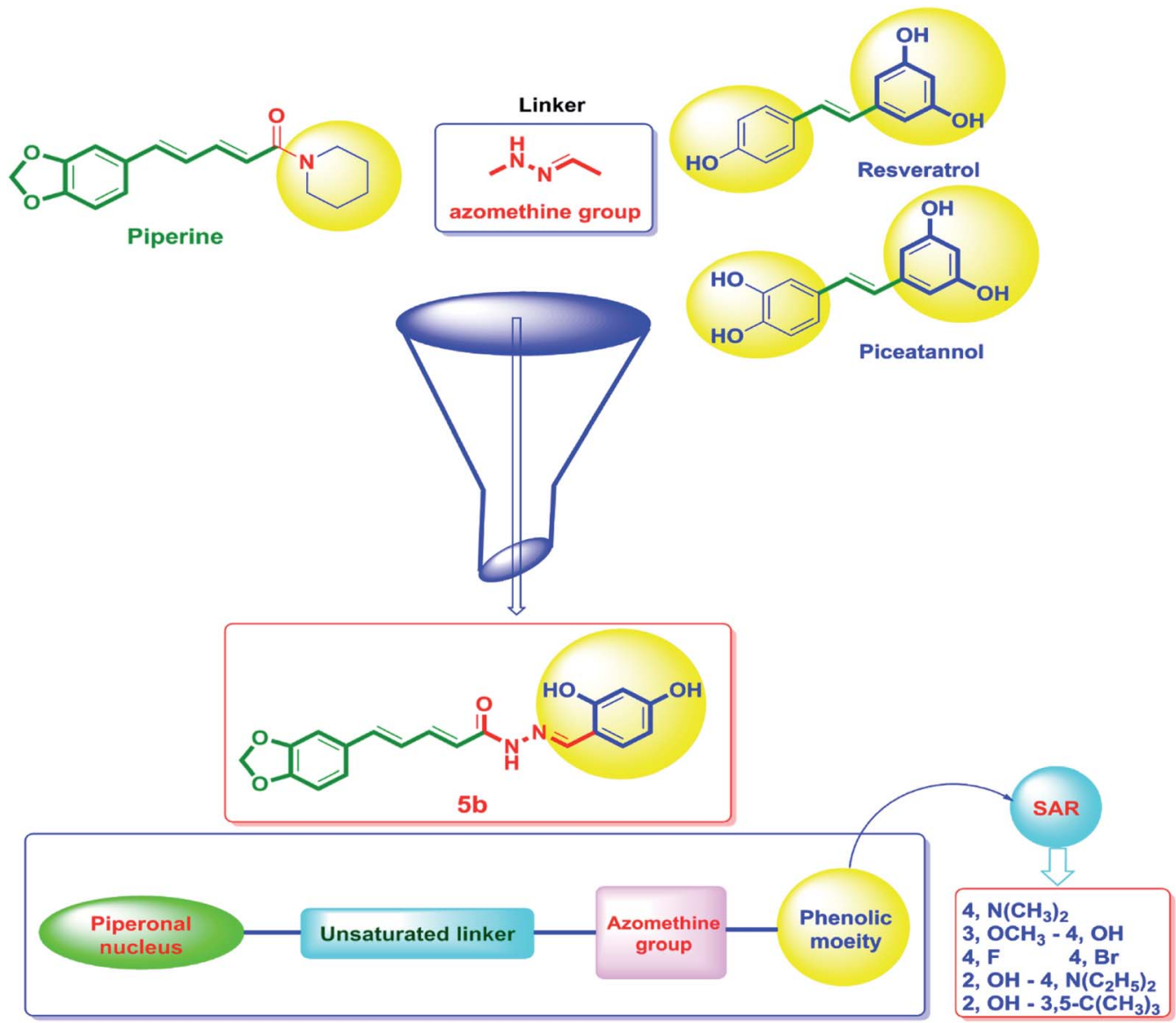

Fig. 3 The design strategy of the novel piperine-resveratrol hybrids. In this design, the piperine backbone was tethered to 1,3-dihydroxyphenyl moiety of resveratrol or piceatannol using an azomethine group as a linker via a fragment-based drug design approach to obtain the final pharmacophore. Then, SAR studies was performed through replacing the phenolic moiety by with various electron-donating and electronwithdrawing substituents.

be clearly rationalized by the small size of the resveratrol structure. Inspirited by these findings, we thought that the elongation or extension of the resveratrol structure to protrude into the hydrophobic acyl-lysine tunnel surrounded by the highly conserved phenylanilines 119, 131, 234, 235 and Val233 or to partially occlude the $\mathrm{NAD}^{+} \mathrm{C}$-pocket would be a promising approach to target and competitively inhibit the Sirt-2 isoform, Fig. 2(C). Thus, our strategy to increase the size of resveratrol or even utilizing its pharmacophoric phenolic moieties was accomplished by hybridization with the piperine structure via a hydrazino-linker in one scaffold, Fig. 3.

Moreover, several reports showed that piperine enhanced the in vivo bioavailability and ADME properties of resveratrol. ${ }^{32}$ Hence, a commercial combination of piperine with resveratrol is currently available in the market and it is promoted to have many health benefits in terms of improving strength and endurance. Additionally, this combination is used as antioxidant, cancer protective and for weight loss. Recently, it was found that the combination of resveratrol with the polyphenolic compounds such as piperine and curcumin has a significant activity against estrogen receptor-positive MCF-7 breast cancer cells however, the authors proposed the action was accomplished through reducing glyoxalase-1 (GLO1) activity. ${ }^{32,33}$
Considering the aforementioned findings, a new hybrid scaffold has been designed bearing the resveratrol pharmacophoric features bound to the piperine backbone using a fragment-based drug design approach in order to target the sirtuins proteins, in particular Sirt-2, as molecular mechanism for the anticancer action of newly synthesized series, Fig. 3. To extend our study and investigate the SAR, a series of piperine derivatives were synthesized by replacement of phenolic moiety with various electron donating and electron withdrawing substituents. The identity of the newly synthesized hybrids $\mathbf{5 a}-\mathbf{h}$ was proved using ${ }^{1} \mathrm{H},{ }^{13} \mathrm{C}$ and ${ }^{19} \mathrm{~F}$ NMR. Furthermore, the singlecrystal structures of $\mathbf{5 a}-\mathbf{f}$ were unambiguously elucidated by Xray crystallography. The anticancer activities of $\mathbf{5 a}-\mathbf{h}$ were evaluated by NCI against sixty cancer cell lines of nine different tissues.

\section{Results and discussion}

\subsection{Chemistry}

Scheme 1 outline the synthetic procedures for key intermediates 2, 3, and target compounds $\mathbf{5 a} \mathbf{a} \mathbf{h}$. According to Scheme $\mathbf{1}$, piperic acid 2 was formed by hydrolyzing piperine (1) with alcoholic $\mathrm{KOH},{ }^{34}$ followed by a reaction with oxalyl chloride in 
the presence of DMF as a catalyst to yield piperic acid chloride 3. ${ }^{35}$ Carbonyl compounds were treated with hydrazine hydrate to yield the corresponding hydrazones $\mathbf{4 a}-\mathbf{h}$, which were then reacted with piperic acid chloride to yield the corresponding compounds $\mathbf{5 a}-\mathbf{h}$. The synthesized compounds were elucidated by ${ }^{1} \mathrm{H},{ }^{13} \mathrm{C}$ and ${ }^{19} \mathrm{~F}$ NMR.

The IR spectrum of $\mathbf{5 b}$ revealed a broad band at $3432-$ $3300 \mathrm{~cm}^{-1}$ related to $(\mathrm{OH})$ and strong stretching band at $1651 \mathrm{~cm}^{-1}$ related to $(\mathrm{C}=\mathrm{O})$, which is consistent with the proposed structure. In the ${ }^{1} \mathrm{H}$ NMR of compound $\mathbf{5 b}$, two common singlet signals one at 13.10-13.18 ppm related to pyridazinone ring (NHCO) and the other at 3.73-3.86 ppm associated with the benzylic protons. The ${ }^{13} \mathrm{C}$ NMR spectra of Va-f showed the characteristic benzylic carbon at $35.1 \mathrm{ppm}$ and the $(\mathrm{C}=\mathrm{O})$ at $168 \mathrm{ppm}$. The olefenic and aromatic carbons appeared at their expected chemical shifts. ${ }^{36-38}$ Interestingly, the prepared compounds are soluble in common organic solvents, such as $\mathrm{CHCl}_{3}$, tetrahydrofuran, and $\mathrm{Et}_{2} \mathrm{O}$, and partially soluble in methanol and ethanol. Compounds 5a-f easily yielded X-ray quality crystals from slow evaporation of a mixture solution of methanol and $\mathrm{CH}_{2} \mathrm{Cl}_{2}$ with the appropriate amount of $\mathbf{5 a}-\mathbf{f}$ at room temperature.<smiles>[R1]C([R1])=NC(=O)/C=C/C=C/c1ccc2c(c1)OCO2</smiles>

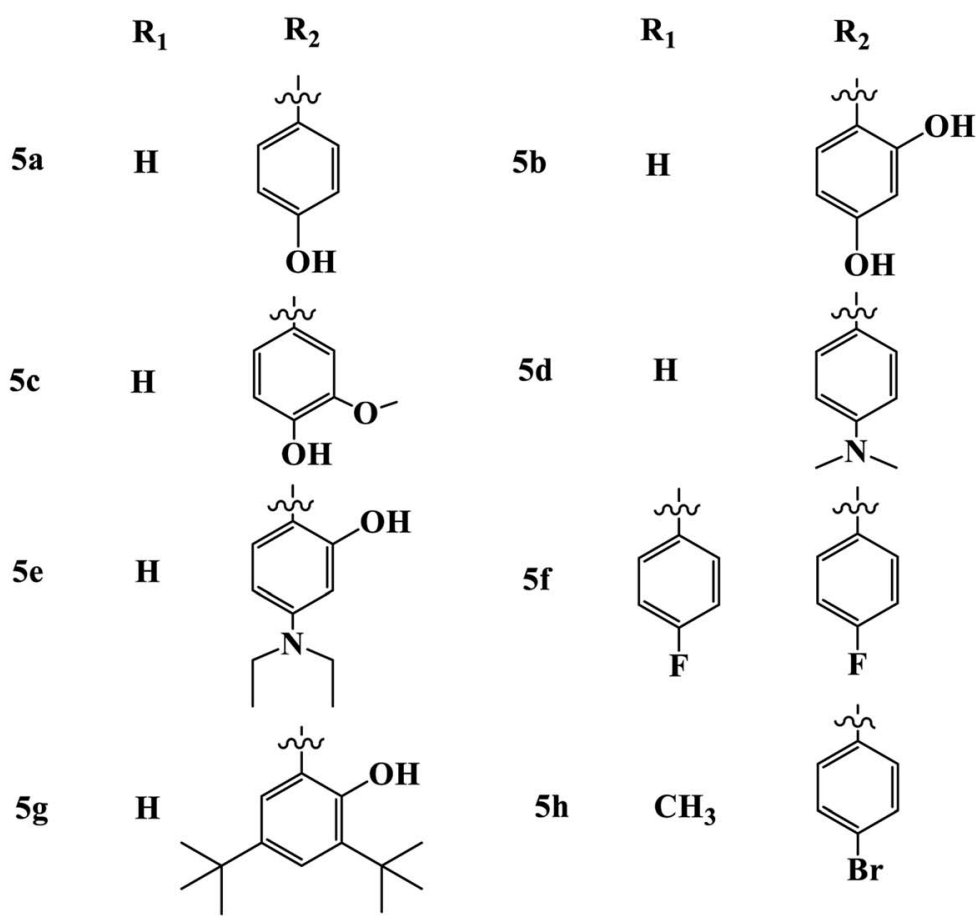

Scheme 1 Synthetic route for the synthesis of novel piperine-resveratrol hybrids $5 a-h$ Reagents and conditions: (a) $\mathrm{KOH}, 95 \% \mathrm{methanol}$, reflux, 48 h, 93\%; (b) $(\mathrm{COCl})_{2}, \mathrm{DCM}$ room temperature, $16 \mathrm{~h}$; (c) $\mathrm{NH}_{2} \mathrm{NH}_{2}, \mathrm{THF}$, reflux $24 \mathrm{~h}$ (d) $\mathrm{DCM}, 0{ }^{\circ} \mathrm{C}, 64-82 \%$. 


\subsection{Biology}

2.2.1. Evaluation of in vitro antiproliferative activity for compounds 5a-h. The antiproliferative activity of the target compounds $\mathbf{5} \mathbf{a}-\mathbf{h}$ was screened against a panel of 60 cancer cell lines according to NCI-guidelines at concentration of $10 \mu \mathrm{M}$. The results for each compound (Table 1) were recorded as the percent of growth inhibition of treated cells compared to untreated control cells. Compound $\mathbf{5 b}\left(\mathbf{R}_{\mathbf{1}}=\mathbf{H}, \mathbf{R}_{\mathbf{2}}=\mathbf{2 , 4}\right.$-dihydroxyphenyl) was the most active among the tested compounds which directly reflects the influences of phenolic moieties on the antiproliferative activity of the title scaffold. $\mathbf{5 b}$ possessing a complete cell death against leukemia HL-60 (TB) and Breast cancer MDA-MB-468 with growth inhibition percentage of -0.49 and -2.83 , respectively. In addition, $5 \mathbf{b}$ recorded significant activity against leukemia cancer cell lines K-562 and MOLT-4, Non-small cell lung cancer cell lines NCI-H322M and NCI-H460, Colon cancer cell lines COLO 205, HCT-15 and HCT116, CNS cancer cell lines SF-295 and SF-539, Melanoma cancer cell lines LOX IMVI and UACC-62, Ovarian cancer cell lines NCI/ ADR-RES, OVCAR-3, and OVCAR-4, Renal cancer cell lines CAKI1, ACHN, and UO-31, and Breast cancer MCF7 cell line with growth inhibition percentage between 80 to 95 . On the other hand, compound 5a $\left(\mathbf{R}_{\mathbf{1}}=\mathbf{H}, \mathbf{R}_{\mathbf{2}}=\right.$ 4-hydroxyphenyl) showed moderate activity against the cancer cell lines studied with growth inhibition percentage between 17 to 73, Table 1 . Compounds 5e $\left(\mathbf{R}_{\mathbf{1}}=\mathbf{H}, \mathbf{R}_{\mathbf{2}}=\right.$ 2-hydroxy-4-diethylaminophenyl) and $\mathbf{5 h}\left(\mathbf{R}_{\mathbf{1}}=\mathbf{C H}_{\mathbf{3}}, \mathbf{R}_{\mathbf{2}}=\mathbf{4}\right.$-bromophenyl) showed good activities against most of cancer cell lines with growth inhibition percentage between 40 to 97 , Table 1 . Compounds 5c, $5 \mathbf{f}$ and $5 \mathrm{~g}$ bearing 3-methoxy-4-hydroxyphenyl, (bis(4-fluorophenyl) methylene) and 3,5-di-tert-butyl-2-hydroxyphenyl, respectively were found to be least effective against the studied cancer cell lines.

2.2.2. Sirtuins inhibitory activity of $\mathbf{5 a - h}$ hybrids. SirtuinTK assay was performed to estimate the Sirtuins inhibitory potential of $\mathbf{5 a}-\mathbf{h}$ (Tables 2 and 3). The results of this test strongly complemented the findings of cancer cell-based assessments. Generally, the piperine-resveratrol $\mathbf{5 a - h}$ hybrids were found to be stronger inhibitors of Sirt 2 than Sirt1 at $5 \mu \mathrm{M}$ and $50 \mu \mathrm{M}$. Of the 8 compounds evaluated, 3 analogs $(\mathbf{5 b}, 5 \mathbf{e}$ and 5h) were more likely to inhibit Sirt2 (>70\% inhibition) than Sirt1 $(<50 \%$ inhibition) at $50 \mu \mathrm{M}$. The other compounds were poor inhibitors of both enzymes. Of these compounds studied, $\mathbf{5 b}\left(\mathbf{R}_{\mathbf{1}}\right.$ $=\mathbf{H}, \mathbf{R}_{\mathbf{2}}=\mathbf{2 , 4}$-dihydroxyphenyl) showed a potent inhibition of SIRT2 $(78 \pm 3 \%$ and $26 \pm 3 \%$ inhibition at $50 \mu \mathrm{M}$ and $5 \mu \mathrm{M}$, respectively). Compared with compound $\mathbf{5 b}$, which has 2,4-dihydroxyphenyl moiety, compound 5a, containing 4-hydroxyphenyl moiety, showed lower potency to inhibit SIRT2 (72 \pm $3 \%$ and $19 \pm 3 \%$ inhibition at $50 \mu \mathrm{M}$ and $5 \mu \mathrm{M}$, respectively). Replacement of the 4-hydroxy group in compound $\mathbf{5 b}$ with 4diethylamino in compound $5 \mathbf{e}$ resulted in a slight reduction of the inhibitory SIRT2 values (74 $\pm 2 \%$ and $24 \pm 3 \%$ inhibition at $50 \mu \mathrm{M}$ and $5 \mu \mathrm{M}$, respectively). A further analysis of the compound pairs $\left[\begin{array}{lll}\mathbf{5 b} & \text { vs. } & \mathbf{5 c}\end{array}\right]$ showed that 5c (containing 4hydroxy-3-methoxyphenyl) would likely have less potent SIRT2 inhibition $(58 \pm 3 \%$ and $17 \pm 3 \%$ inhibition at $50 \mu \mathrm{M}$ and $5 \mu \mathrm{M}$, respectively) than compound $\mathbf{5 b}$ (Table 3). Notably, 5h, containing 4-bromophenyl moiety, showed promising potency with $75 \pm 3 \%$ and $22 \pm 5 \%$ SIRT2 inhibition at $50 \mu \mathrm{M}$ and $5 \mu \mathrm{M}$, respectively.

We then evaluated the $\mathbf{5 b}, \mathbf{5 e}$ and $\mathbf{5 h} \mathrm{IC}_{50}$ values against SIRT2, all of which inhibited SIRT2 by more than $75 \%$ at $50 \mu \mathrm{M}$ compared to the SIRT2 selective inhibitor AGK2 as a reference. The results are listed in Table 4 . Compound $\mathbf{5 b}$ was the most potent one among the tested derivatives, with $\mathrm{IC}_{50}$ value of $21 \pm$ $3 \mu \mathrm{M}$ in comparison to the reference AGK2 $\left(\mathrm{IC}_{50}=13.9 \pm 1\right.$ $\mu \mathrm{M}){ }^{39}$

\subsubsection{Cell cycle analysis and apoptosis assay}

2.2.3.1. Cell cycle analysis. Cell cycle analysis was conducted for the most active compound $\mathbf{5 b}$ against human pancreatic cancer cell line MCF-7. The percentage of MCF-7 cells in the G0/ G1 phase of the control cell cycle was $53.64 \%$, with a significant decrease to $35.08 \%$ following treatment with compound $\mathbf{5 b}$, while the percentage of cells in the $S$ phase was marginally reduced with compound $\mathbf{5 b}(35.56 \%)$ compared to the control (36.41\%) (Fig. 4). The percentage of MCF-7 human pancreatic cancer cell line in the $\mathrm{G} 2 / \mathrm{M}$ phase increased to $34.36 \%$ following treatment with compound $\mathbf{5 b}$. In addition, it is clear that the percentage of apoptotic cells in the pre-G1 process increased from $1.79 \%$ for control of untreated MCF-7 human pancreatic cancer cells to $17.34 \%$ and $22.17 \%$ for controlled $5 \mathbf{b}$ and doxorubicin cells, respectively (Fig. 4, Table 5). According to the above results, compound $\mathbf{5 b}$ exhibited mainly cell cycle arrest during the Pre-G1 and G2/M phases. In addition, it is clear that the compound studied is not cytotoxic but antiproliferative, triggering programmed cell death and cell cycle arrest.

\subsection{Description of crystals 5a-f and Hirschfeld surface analysis}

The Hirschfeld surfaces and fingerprint plots can be utilized to identify a type and region of intermolecular interactions, which are capable of being generated using Crystal-Explorer software. ${ }^{\mathbf{4 0}}$ Molecular Hirschfeld surface in a crystal structure is constructed based on the electron distribution. Its normalized contact distance $\left(d_{\text {norm }}\right)$ based on both $d_{\mathrm{e}}, d_{\mathrm{i}}$ and van der Waals radii of the atom is listed in the following equation. Then, intermolecular contacts in the crystal can be analyzed by a combination of $d_{\mathrm{e}}$ and $d_{\mathrm{i}}$ in the form of a 2D fingerprint plot as listed in the below equation. ${ }^{41}$ Complementary regions are visible in the fingerprint plots where one molecule acts as a donor $\left(d_{\mathrm{e}}>d_{\mathrm{i}}\right)$ and the other as an acceptor $\left(d_{\mathrm{e}}<d_{\mathrm{i}}\right)$. The fingerprint plots can be divided into highlighting particular close interactions between the two atoms. ${ }^{42}$ This decomposition enables the separation of contributions from different interaction types in the full fingerprint.

$$
d_{\text {norm }}=\left(d_{\mathrm{i}}-r_{\mathrm{i}}^{\mathrm{vdw}}\right) / r_{\mathrm{i}}^{\mathrm{vdw}}+\left(d_{\mathrm{e}}-r_{\mathrm{e}}^{\mathrm{vdw}}\right) / r_{\mathrm{e}}^{\mathrm{vdw}}
$$

Crystals of $\mathbf{5 b}$ were determined at room temperature. X-ray experiments indicate that there are each one complete $\mathbf{5 b}$ and one methanol solvent molecule in its asymmetric unit. The 
Table 1 One dose assay of nine different cancer cell types of compounds $5 a-h^{a}$

Growth\% inhibition

Subpanel cancer cell lines

Leukemia

CCRF-CEM

HL-60(TB)

K-562

MOLT-4

RPMI-8226

SR

Non-small cell lung cancer

A549/ATCC

EKVX

HOP-62

HOP-92

NCI-H226

NCI-H23

NCI-H322M

NCI-H460

NCI-H522

Colon cancer

COLO 205

HCC-2998

HCT-116

HCT-15

HT29

KM12

SW-620

CNS cancer

SF-268

SF-295

SF-539

SNB-19

SNB-75

U251

\section{Melanoma}

LOX IMVI

MALME-3M

M14

MDA-MB-435

SK-MEL-2

SK-MEL-28

UACC-257

UACC-62

Ovarian cancer

IGROV1

OVCAR-3

OVCAR-4

OVCAR-5

OVCAR-8

NCI/ADR-RES

SK-OV-3

Renal cancer

786-0

ACHN

CAKI-1

RXF 393

SN12C
$5 a \quad 5 b$

$5 c$

5d

$\begin{array}{ll}12.13 & 20.48 \\ - & - \\ 10.48 & \mathbf{5 6 . 1 1} \\ - & - \\ 15.33 & - \\ - & \mathbf{6 2 . 0 5}\end{array}$

63.94

$\begin{array}{ll}- & 79.77 \\ - & 72.86\end{array}$

- $\quad 46.60$

$\begin{array}{ll}- & 62.41\end{array}$

$-\quad 70.00$
$-\quad 18.48$

18.48

- 22.76

82.25

86.03

78.87

$\begin{array}{ll}- & \mathbf{8 6 . 0 3}\end{array}$

61.09
$-\quad 61.33$

-

39.67

- 33.35

19.77

91.33

83.03

51.91

76.61

73.5

17.15

- 17.56

-

26.97

-

38.53

-

17.10

73.02

$-$

$-$

28.50

75.57

86.23

85.66

$\mathbf{5 0 . 8 7}$

35.98

68.74

24.72

71.10

90.27

$12.67 \quad 90.76$

12.67 .55
$-\quad 57.21$

- $\quad 77.21$

-94.85
$-\quad 93.00$

94.85
$-\quad 73.00$

- $\quad 70.98$

$-$

25.08

-
70.98

90.35

42.15

67.24
-

$\begin{array}{ll}- & - \\ - & - \\ - & - \\ - & - \\ 18.28 & - \\ - & - \\ 14.74 & - \\ -21.98 & - \\ & 11.67\end{array}$

46.69

47.83

71.47

51.62

50.53

50.33

66.83

80.25

87.48

$\begin{array}{ll}- & 60.08\end{array}$

-
$-\quad 45.98$

-

24.23

-

14.25

-

92.14

78.73

32.24

69.83

67.68

66.32

58.30

77.28

38.99

41.19

56.75

11.11

22.24

70.14

-

-

$-$

16.06

10.14

$\begin{array}{ll}- & 10.14 \\ - & - \\ - & - \\ - & - \\ - & - \\ - & -\end{array}$

-

-

$-$

-
81.77

43.47

63.64

$\mathbf{5 1 . 1 2}$

34.33

47.95

75.82

70.87

61.80

95.06

84.74

39.11

67.09

82.45

60.49
52.78

74.37

70.70

27.41

45.91 5f

$5 \mathbf{h}$

$\begin{array}{lll}- & - & 44.26 \\ - & - & 15.88 \\ - & - & 40.06 \\ - & - & 25.29 \\ - & - & 19.41 \\ 36.26 & - & 93.31\end{array}$

$-$

$-$

12.49

24.99

33.23

11.51

24.10

36.51

60.40

19.91

$\begin{array}{lll}- & - & - \\ - & - & 10.78 \\ - & - & 12.34 \\ - & - & 36.30 \\ - & - & - \\ - & - & 24.89 \\ - & - & 25.44\end{array}$

-
-
-
-

-
-
-
32.95
-

32.46

12.47

14.48

68.09

16.04

$\begin{array}{lll}- & 12.05 & 38.29 \\ - & - & 28.67 \\ - & - & 26.74 \\ - & - & 13.60 \\ - & - & 11.01 \\ - & - & 14.25 \\ - & - & 12.00 \\ 12.19 & - & 28.51\end{array}$

$\begin{array}{lll}12.09 & 14.13 & 29.67 \\ - & - & 24.42 \\ - & - & 65.24 \\ - & - & 10.69 \\ - & - & 24.67 \\ - & - & 33.86 \\ - & - & -\end{array}$

$\begin{array}{ll}- & - \\ - & - \\ 12.79 & - \\ - & -\end{array}$

$\begin{array}{ll}- & 14.63 \\ - & 24.09 \\ - & 28.09 \\ - & - \\ - & 12.40\end{array}$


Table 1 (Contd.)

\begin{tabular}{|c|c|c|c|c|c|c|c|c|}
\hline \multirow[b]{2}{*}{ Subpanel cancer cell lines } & \multicolumn{8}{|c|}{ Growth\% inhibition } \\
\hline & $5 \mathbf{a}$ & $5 \mathbf{b}$ & $5 c$ & $5 d$ & $5 e$ & $5 f$ & $5 g$ & $5 h$ \\
\hline UO-31 & 39.21 & 88.57 & 14.03 & 23.71 & 75.03 & 18.30 & 27.88 & 44.91 \\
\hline \multicolumn{9}{|l|}{ Prostate cancer } \\
\hline \multicolumn{9}{|l|}{ Breast cancer } \\
\hline MCF7 & 28.77 & 85.87 & 20.13 & 43.56 & 80.48 & - & - & 38.66 \\
\hline MDA-MB-231/ATCC & 17.21 & 65.61 & - & - & 56.75 & - & - & 21.03 \\
\hline HS $578 \mathrm{~T}$ & - & 29.82 & - & - & 31.90 & - & - & 86.45 \\
\hline BT-549 & 21.48 & 72.73 & 13.62 & - & 48.23 & - & - & - \\
\hline
\end{tabular}

Table 2 Inhibitory activities of $5 \mathrm{a}-\mathrm{h}$ against human SIRT1

\begin{tabular}{lrr}
\hline & \multicolumn{2}{c}{$\%$ inhibition of SIRT1 } \\
\cline { 2 - 3 } Compound & $5 \mu \mathrm{m}$ & $50 \mu \mathrm{m}$ \\
\hline $\mathbf{5 a}$ & $13 \pm 3$ & $42 \pm 3$ \\
$\mathbf{5 b}$ & $18 \pm 3$ & $45 \pm 3$ \\
$\mathbf{5 c}$ & $12 \pm 1$ & $38 \pm 3$ \\
$\mathbf{5 d}$ & $11 \pm 2$ & $48 \pm 3$ \\
$\mathbf{5 e}$ & $20 \pm 5$ & $44 \pm 2$ \\
$\mathbf{5 f}$ & $14 \pm 4$ & $39 \pm 3$ \\
$\mathbf{5 g}$ & $9 \pm 2$ & $35 \pm 1$ \\
$\mathbf{5 h}$ & $16 \pm 5$ & $44 \pm 3$ \\
\end{tabular}

Table 3 Inhibitory activities of $5 \mathrm{a}-\mathrm{h}$ against human SIRT2

\begin{tabular}{lll}
\hline & \multicolumn{2}{l}{$\%$ inhibition of SIRT2 } \\
\cline { 2 - 3 } Compound & $5 \mu \mathrm{m}$ & $50 \mu \mathrm{m}$ \\
\hline $\mathbf{5 a}$ & $19 \pm 3$ & $72 \pm 3$ \\
$\mathbf{5 b}$ & $26 \pm 3$ & $78 \pm 3$ \\
$\mathbf{5 c}$ & $17 \pm 3$ & $58 \pm 3$ \\
$\mathbf{5 d}$ & $18 \pm 2$ & $70 \pm 3$ \\
$\mathbf{5 e}$ & $24 \pm 3$ & $74 \pm 2$ \\
$\mathbf{5 f}$ & $20 \pm 4$ & $69 \pm 3$ \\
$\mathbf{5 g}$ & $19 \pm 2$ & $55 \pm 1$ \\
$\mathbf{5 h}$ & $22 \pm 5$ & $75 \pm 3$
\end{tabular}

whole molecule shows a nearly flat configuration due to these several double bonds. The Hirschfeld surfaces of compound $\mathbf{5 b}$

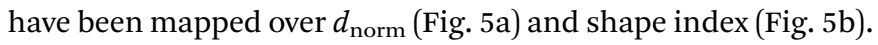
The intermolecular interactions mainly originated from hydroxyl oxygen and acyl hydrazone nitrogen atoms can be seen in the Hirschfeld surface as the bright red areas in Fig. 5a, and the light red spots are corresponding to $\mathrm{C}-\mathrm{H} \cdots \mathrm{O}$ and $\mathrm{C}-\mathrm{H} \cdots \pi$ interactions. The $\mathrm{O} \cdots \mathrm{H} / \mathrm{H} \cdots \mathrm{O}$ intermolecular interactions (30.4\%) appear as distinct spikes in the 2D fingerprint plot (Fig. 5d). In the fingerprint plots, there are two sharp spikes in the lower left of the plots due to the $\mathrm{O} / \mathrm{N}-\mathrm{H} \cdots \mathrm{O}$ hydrogen bonds (Fig. 5c). The proportion of $\mathrm{O} \cdots \mathrm{H} / \mathrm{H} \cdots \mathrm{O}$ interactions comprises $30.4 \%$ of the total Hirschfeld surfaces. The points in the $\left(d_{\mathrm{i}}, d_{\mathrm{e}}\right)$ regions around $(1.168,1.107)$ from the fingerprint plots belong to $\mathrm{C}-\mathrm{H} \cdots \pi$ interactions $(17.2 \%)$ (Fig. $5 \mathrm{e}$ ) which is mainly existing between the benzene ring and the methanol solvent at $(2-$ $x, 1-y, z) . \pi \cdots \pi$ interactions are not represented because there are no typical 'wings' at the top left and bottom right of the twodimensional fingerprint plot (Fig. 5f), occupying $c a$. $8.3 \%$ of the total Hirschfeld surface. For the crystal packing, the molecules of $\mathbf{5 b}$ are linked by these $\mathrm{O} / \mathrm{N}-\mathrm{H} \cdots \mathrm{O}$ hydrogen bonds into a twodimensional layer structure parallel to the (001) plane. These (001) layer structures are further linked into a threedimensional network.

In the crystal structure of 5a (Fig. S9†), there is one complete molecule and one methanol molecule in its asymmetric unit in which the component ions are linked into a one-dimensional hydrogen-bonded chain running along the [010] axis. A Hirschfeld surface analysis indicates that the $\mathrm{H} \cdots \mathrm{O}(25.6 \%)$, $\mathrm{H} \cdots \mathrm{C}(22.1 \%), \mathrm{C} \cdots \mathrm{C}(5.9 \%)$ and $\mathrm{H} \cdots \mathrm{H}(38.7 \%)$ contacts in $5 \mathrm{a}$ are comparable to those in crystal structure of $\mathbf{5 b}$.

Table $4 \quad I C_{50}$ values for the inhibitory activity of compounds $5 \mathrm{~b}, 5 \mathrm{e}$ and $5 \mathrm{~h}$ against SIRT2 enzyme

\begin{tabular}{lr}
\hline Compound & $\mathrm{IC}_{50}(\mu \mathrm{m})$ \\
\hline $\mathbf{5 b}$ & $21 \pm 3$ \\
$\mathbf{5 e}$ & $23 \pm 2$ \\
$\mathbf{5 h}$ & $26 \pm 3$ \\
AGK2 (ref. 39) & $13.9 \pm 1$
\end{tabular}



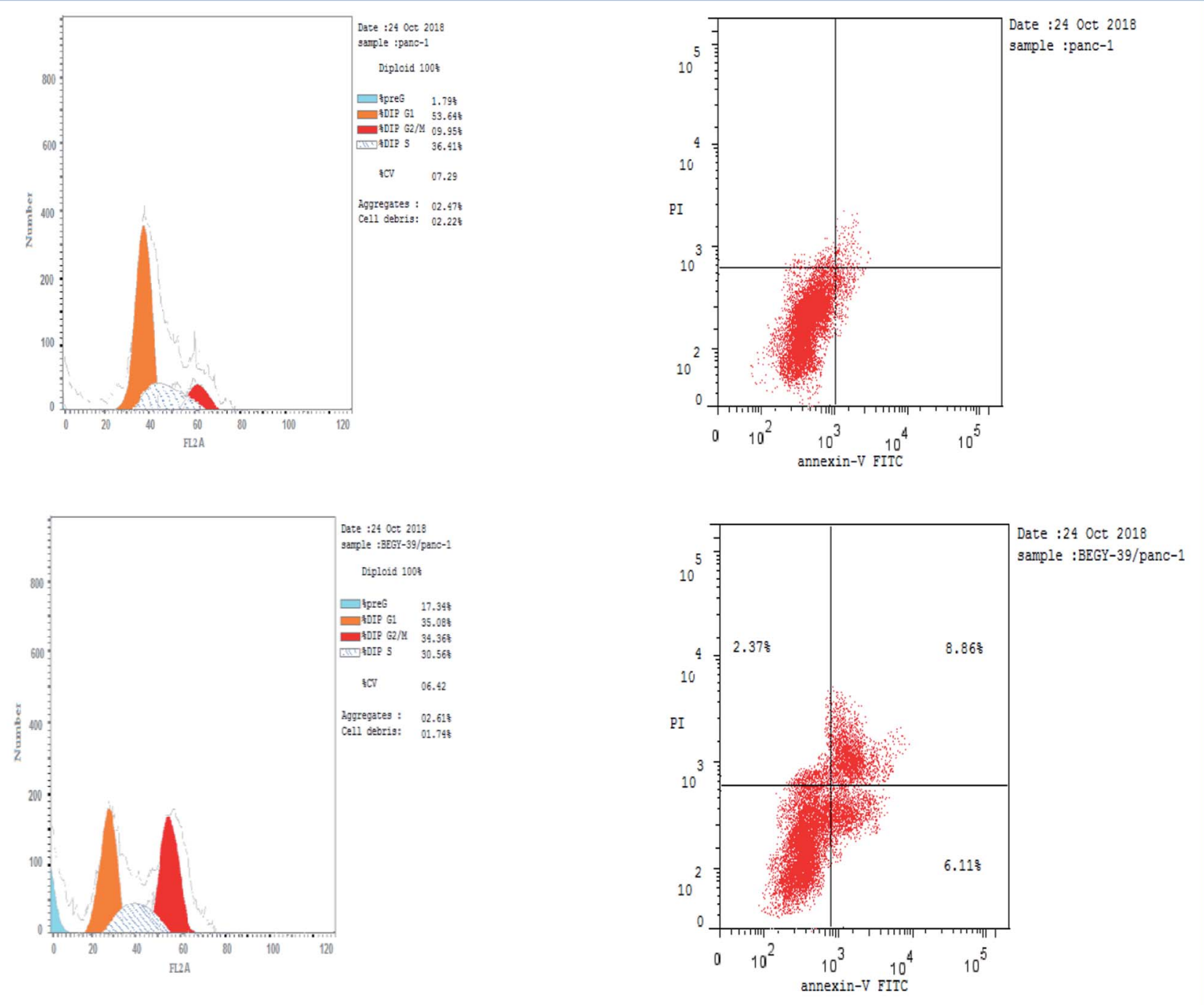

Fig. 4 Cell cycle analysis of 5b in human pancreatic cancer cell line MCF-7.

In the crystal structure of $\mathbf{5 c}$, there is one complete molecule in its asymmetric unit in which the component ions are linked into a two-dimensional hydrogen-bonded layer structure parallel to the plane (20-1). A Hirschfeld surface analysis indicates that the contacts of $\mathrm{H} \cdots \mathrm{O}, \mathrm{H} \cdots \mathrm{C}, \mathrm{C} \cdots \mathrm{C}$ and $\mathrm{H} \cdots \mathrm{H}$ in the crystal packing of $5 \mathrm{c}$ are $22.8 \%, 28.8 \%, 1.4 \%$ and $35.3 \%$ respectively (Fig. S10 $\dagger$ ). In $\mathbf{5 d}$, there is one complete molecule and two water molecules in its asymmetric unit in which the component ions are linked into a two-dimensional hydrogen-

Table 5 Apoptosis induction analysis of compound $5 \mathrm{~b}$

\begin{tabular}{llllll}
\hline & & \multicolumn{2}{c}{ Apoptosis } & \\
\cline { 3 - 5 } & & & & \\
Sample code & Cell line & \% total & \% early & \% late & necrosis \\
\hline 5b & MCF-7 & 6.16 & 2.74 & 2.29 & 1.13 \\
Control & MCF-7 & 1.72 & 0.88 & 0.23 & 0.61
\end{tabular}

bonded network parallel to the (001) plane. A Hirschfeld surface analysis for the host molecule indicates that the $\mathrm{H} \cdots \mathrm{O}$, $\mathrm{H} \cdots \mathrm{C}$ and $\mathrm{C} \cdots \mathrm{C}$ contacts including their reciprocal contacts are $19.2 \%, 27.1 \%$ and $3.2 \%$ of the total surface, respectively (Fig. S11†).

In $\mathbf{5 e}$, there is each one host molecule and one methanol molecule in its asymmetric unit. Analysis indicates the component ions are firstly linked into a one-dimensional hydrogen-bonded chain running along the [010] axis. These neighboring [010] chains are linked into a three-dimensional network by a combination of $\mathrm{C}-\mathrm{H} \cdots \pi$ and $\pi \cdots \pi$ interactions. A Hirschfeld surface analysis indicates that the $\mathrm{H} \cdots \mathrm{O}(19.7 \%)$, $\mathrm{H} \cdots \mathrm{C}(17.4 \%), \mathrm{C} \cdots \mathrm{C}(5.4 \%)$ and $\mathrm{H} \cdots \mathrm{H}(51.5 \%)$ contacts are also comparable to those in crystal structures above mentioned (Fig. S12 $\dagger$ ). In the crystal of $\mathbf{5 f}$ (Fig. S13 $\uparrow$ ), a dimer is formed by a pair of complementary $\mathrm{N}-\mathrm{H} \cdots \mathrm{O}$ hydrogen bonds. A Hirschfeld surface analysis indicates that the $\mathrm{H} \cdots \mathrm{O}$ (including the reciprocal contacts) contacts comprise $13.9 \%$ of the total surface. 


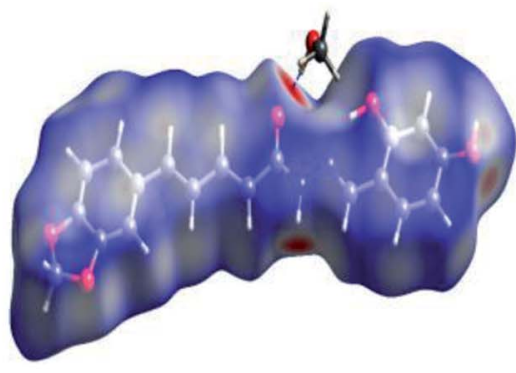

(a)

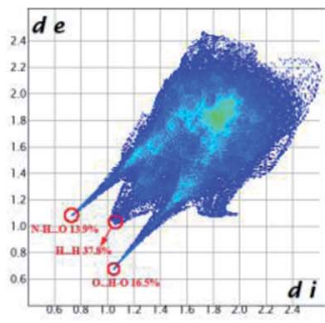

(c)

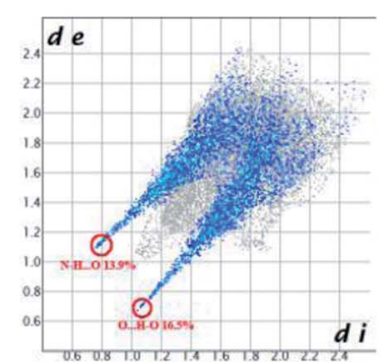

(d)

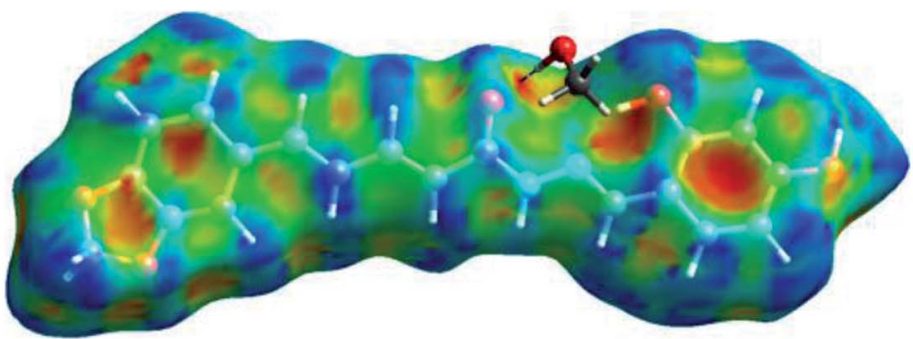

(b)

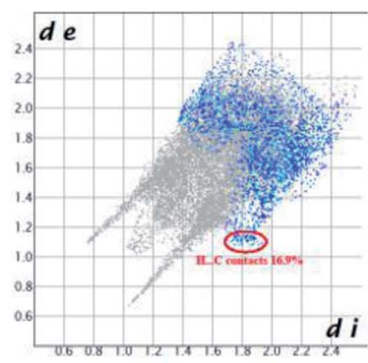

(e)

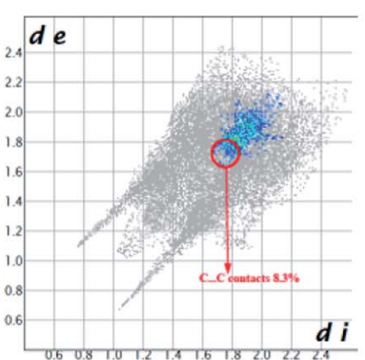

(f)

Fig. 5 Hirshfeld surfaces in $5 \mathrm{~b}$ mapped with (a) $d_{\text {norm; }}$ (b) shape index, (c) full fingerprint plot; (d) $\mathrm{H} \cdots \mathrm{O}$ contacts $(\mathrm{O}-\mathrm{H} \cdots \mathrm{O}$ and $\mathrm{N}-\mathrm{H} \cdots \mathrm{O}$ ); (e) $\mathrm{H} \cdots \mathrm{C}$ contacts $(\mathrm{C}-\mathrm{H} \cdots \pi)$ and (f) $\mathrm{C} \cdots \mathrm{C}$ contacts $(\pi \cdots \pi)$.

The $\mathrm{H} \cdots \mathrm{C}(\mathrm{C}-\mathrm{H} \cdots \pi, 18.9 \%)$ and $\mathrm{C} \cdots \mathrm{C}(\pi \cdots \pi, 5.3 \%)$ are both comparable to those in $\mathbf{5 b}$.

From the Hirschfeld analysis, we can obviously see that the $\mathrm{O} / \mathrm{N}-\mathrm{H} \cdots \mathrm{O}$ hydrogen bonds are the main driving forces in the crystal packing. The $\mathrm{C}-\mathrm{H} \cdots \pi$ interactions also play an important role in the crystal aggregates. However, the $\pi \cdots \pi$ interactions comprise the least of the total Hirschfeld surface in these five structures. We can also find that the lateral hydroxyl oxygen and acyl hydrazone nitrogen atoms are in favor of hydrogenbonding to some other acceptors. To sum up above mentioned discussion, one can find that the $\mathrm{O} / \mathrm{N}-\mathrm{H} \cdots \mathrm{O}$ hydrogen bonds are preferred in the crystallization state. Although a crystallization state cannot be completely a representation of a solution state, it can still give us some hints when these molecules are used an antiproliferative inhibitors they may firstly interact with the target position of a protein through hydrogen bonds (vide infra).

\subsection{Molecular docking study}

In an attempt to rationalize the obtained in vitro Sirt-2 assay results, a molecular docking study of the most potent compound $\mathbf{5 b}$ into the active site of human Sirt-2 was performed to elucidate the possible underlying inhibitory mechanisms and to predict the binding mode and the interactions that can be formed. The 3D crystal structure of Sirt-2 (PDB code: $4 \mathrm{RMG}$ ) in complex with SirReal2 ligand and Co-factor $\mathrm{NAD}^{+}$was used after preparation. The docking simulation was carried out using Ligand Fit embedded in Discovery Studio software 2.5 (San Diego, USA) according the reported method. ${ }^{4-46}$ Analysis of the top-ranked pose of compound $\mathbf{5 b}$ demonstrated several plausible molecular interactions and various binding patterns, Fig. 6A. It was reported that the active site of Sirt- 2 could be divided into several sites. The C-pocket accommodates the nicotinamide moiety of the co-factor $\mathrm{NAD}^{+}$while the acetyl-Lys substrate binding channel is formed by several hydrophobic phenylalanine's. In addition, there is a pocket close to the Cpocket and link the inducible selectivity pocket in Sirt-2 with the acyl-Lys tunnel called extended C-site, Fig. 6(B). ${ }^{47,48}$

From a precise inspection of the results, it was conceptualized that there are two possible different hypotheses or binding patterns can be used to rationalize the inhibitory activity of our compound 5b against SIRT-2: (I) our newly synthesized hybrid molecule $\mathbf{5 b}$ adopts a very similar binding mode consistent with that of the co-crystallized ligand, SirReal 2 where it binds to the extended C-site as well as to the reported selectivity pocket that formed by two loops of the hinge region connecting the Rossmann-fold and zinc-binding domains. The binding pattern analysis revealed that 1,3-dihydroxyphenyl moiety of $\mathbf{5 b}$ can be accommodated into the lipophilic selectivity pocket in a manner similar to the dimethyl mercapto-pyrimidine residue of SirReal 2 maintaining the same $\pi-\pi$ stacking with Phe190. In addition, two hydrogen bonds were formed between the two hydroxyl groups of $\mathbf{5 b}$ and Ala135 and Ile169 residues. The rest of the $\mathbf{5 b}$ kinked conformation occupies the Extended C-site adjacent to the C-pocket and it is oriented towards the acetyllysine substrate tunnel. The benzodioxolyl moiety of $\mathbf{5 b}$ protrudes into the substrate channel forming hydrophobic interactions with Phe119, Phe131, Ile232, Val233 and Phe234 amino acids. This bulky benzodioxolyl moiety equivalent to the 


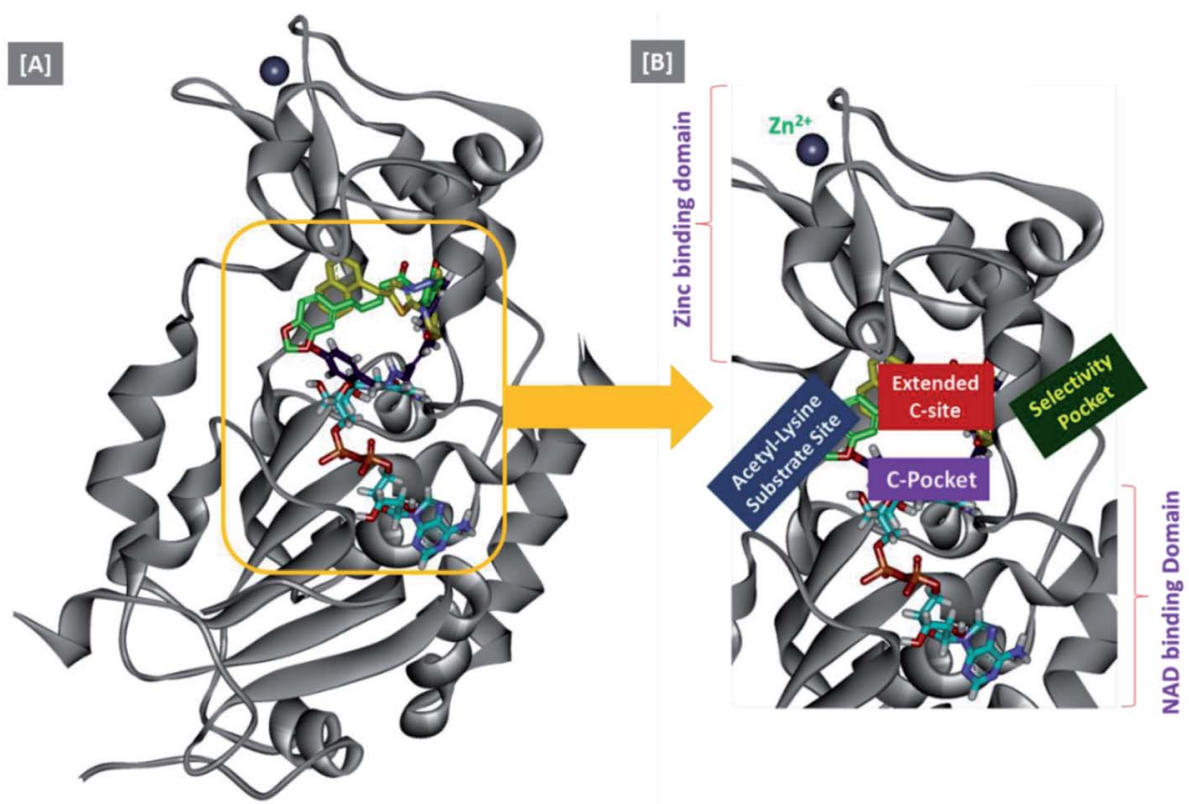

Fig. 6 Docking of compound 5b into SIRT-2 3D structure (pdb code: 4RMG). (A) Overlay of the top docked poses 5b (green and violet) and SirReal-2 (yellow) as a co-crystallized ligand into the Sirt-2 binding site where the Sirt-2 protein is represented as secondary structure displayed in a flat ribbon style (cartoon) colored in black-white; (B) labelling of the different binding pockets of Sirt- 2 protein. The NAD ${ }^{+}$co-factor (cyan) is displayed in stick.

naphthyl moiety of SirReal2, is thought to force the acetyl-lysine out of its physiological position in a competitive inhibitory manner. Interestingly, the $\mathbf{5 b}$ structure is longer than sirReal2 one which in turn will likely compete with the acyl-Lys substrate in a stronger way. In this hypothesis, $\mathbf{5} \mathbf{b}$ does not interfere with the C-pocket where nicotinamide moiety of $\mathrm{NAD}^{+}$binds, Fig. 7A-C.
(II) Another considerable binding mode was observed where 5b binds in an inverted fashion to what was adopted in the former hypothesis. It was found that the benzodioxolyl moiety induces the formation of the selectivity pocket instead of the dihydroxyphenyl in a similar manner to that of sirReal2 forming the reported $\pi-\pi$ stacking with Phe190. However, the dihydroxyphenyl moiety was oriented downwards toward the C-

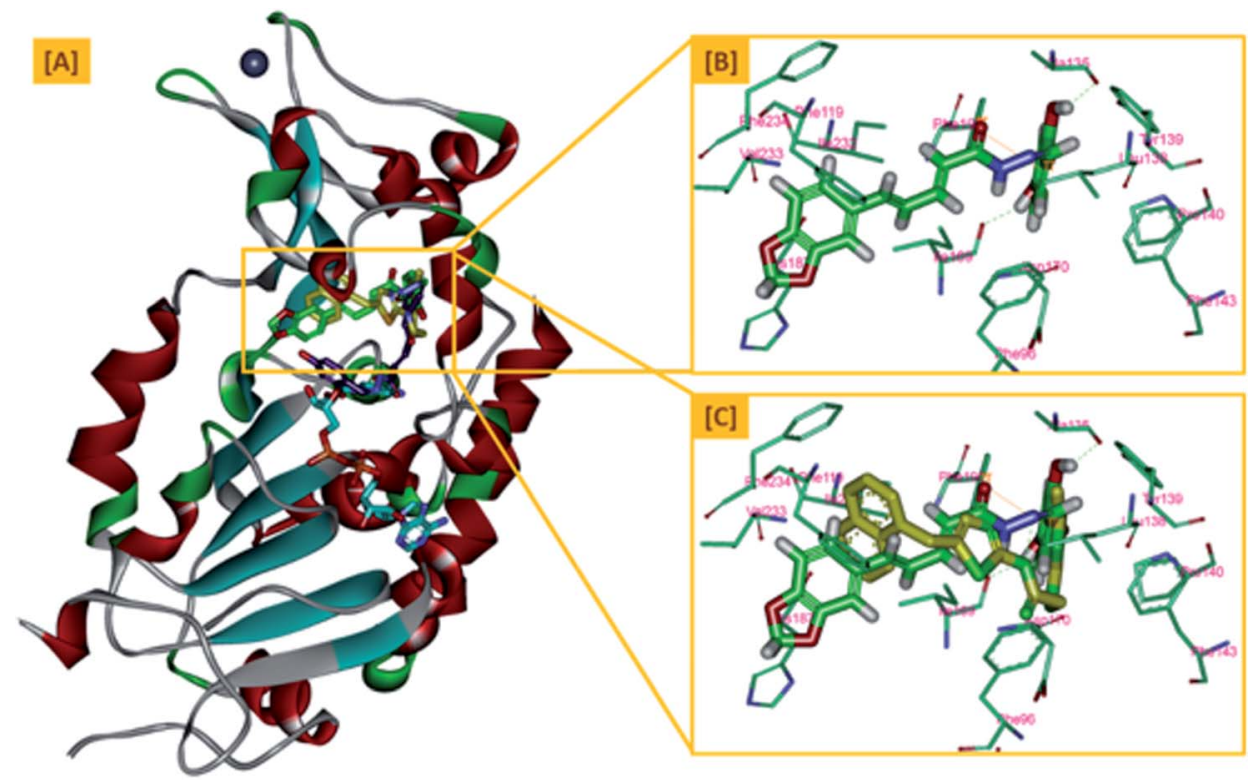

Fig. 7 The first hypothesis of binding pattern of $5 b$ inside Sirt-2 active site; (A) overlay of the top docked poses $5 b$ (green and violet) and SirReal-2 (yellow) as a co-crystallized ligand into the secondary structure of Sirt-2 active pocket; (B) the interactions and binding mode of $5 \mathrm{~b}$ (green) inside the Sirt-2 active sites (extended C-pocket and selectivity pocket); (C) superimposition of $5 \mathrm{~b}$ (green) and SirReal2 (yellow). The poses were rendered as stick model. $\pi-\pi$ interactions were represented as orange solid line. Hydrogen bonds were represented as dashed green lines. 


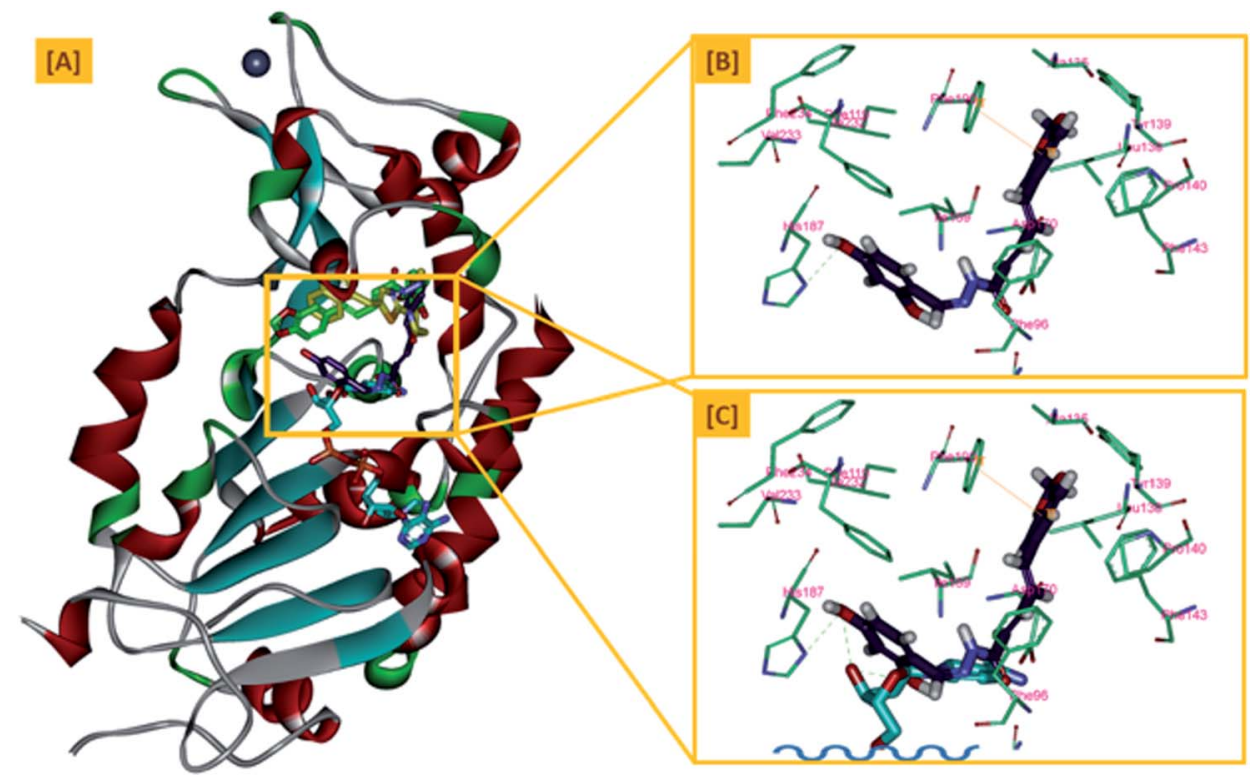

Fig. 8 The second hypothesis of binding pattern of $5 \mathrm{~b}$ inside Sirt- 2 active site; (A) overlay of the top docked poses $5 \mathrm{~b}$ (green and violet) and SirReal-2 (yellow) as a co-crystallized ligand into the secondary structure of Sirt-2 active pocket; (B) the interactions and binding mode of $5 \mathrm{~b}$ (violet) inside the Sirt-2 active sites (Extended C-pocket and selectivity pocket); (C) the window shows magnification of the possible clash between $5 \mathrm{~b}$ (violet) and the $\mathrm{NAD}^{+} \mathrm{co}$-factor (cyan). The rest of $\mathrm{NAD}^{+}$was removed for clarity. The poses were rendered as stick model. $\pi-\pi$ interactions were represented as orange solid line. Hydrogen bonds were represented as dashed green lines.

pocket where the nicotinamide moiety of $\mathrm{NAD}^{+}$binds and initializes the deacetylation reaction. This conformation is stabilized by forming a hydrogen bond with His187. Another hydrophobic interaction between the unsaturated alkenyl chain of $\mathbf{5 b}$ and the gate keeper, Phe96 residue, which helps nicotinamide to release and prevents the backward reaction was observed. It was also noted that $\mathbf{5 b}$ was highly distorted from the extended C-site or the substrate tunnel and did not have strong hydrophobic contact with Phe119, Phe131, Ile232, Val233 and Phe234 amino acids residue, Fig. 8A-C. This hypothesis suggested that $\mathbf{5 b}$ might partially occupy the C-pocket and occlude or compete with nicotinamide moiety of $\mathrm{NAD}^{+}$in contrary to the sirReal2 mechanism which a is partially non-competitive towards $\mathrm{NAD}^{+}$. We think that the former hypothesis is a much more reasonable explanation for the inhibitory activity of $\mathbf{5 b}$ against Sirt- 2 where it shows the highest ranked binding pattern with the lowest energy score. Moreover, targeting both selectivity pocket and the substrate channel by linking two distinct moieties in one scaffold is much more acceptable and significant mechanism for inhibition of Sirt-2. Indeed, we will need further kinetic competition studies to distinguish and prove one of these two inhibitory mechanisms. However, these results support the hypothesis that targeting either the acyl-Lys substrate binding site or $\mathrm{NAD}^{+}$co-factor C-pocket represents a useful approach to develop novel and potent SIRT2 competitive inhibitors.

\section{Conclusion}

In this study, a series of piperine-resveratrol hybrids $\mathbf{5 a - h}$ was designed and synthesized as inhibitors of Sirt-2. A panel with sixty cancer cell lines of nine different tissues in compliance with the NCI protocol has been utilized for the evaluation of $\mathbf{5 a}-\mathbf{h}$ hybrids. Compounds $5 \mathbf{b}, \mathbf{5 e}$ and $\mathbf{5 h}$ showed significant antiproliferative activity. 5a-h were found to be more potent inhibitors of Sirt-2 than Sirt-1. Results of cell cycle investigation showed that 3.64\% of pre-G1 apoptosis was induced by compound $5 \mathbf{b}$ on MCF-7 with a high percentage of cell accumulation in G2-M phase. In these complexes with the hydroxyl groups, the component ions are mainly linked into a 3D framework by a combination of $\mathrm{O}-\mathrm{H} \cdots \mathrm{O}$ hydrogen bonds, $\mathrm{C}-\mathrm{H} \cdots \mathrm{O}, \mathrm{C}-\mathrm{H} \cdots \pi$ and $\pi \cdots \pi$ interactions. Hirschfeld surface analysis indicates that $\mathrm{O}-\mathrm{H} \cdots \mathrm{O}$ hydrogen bonds consist of $c a .20 \%$ of the total surface, which indicate that in the biological system the $\mathrm{O}-\mathrm{H} \cdots \mathrm{O}$ interaction may be mainly attributed to their biological characteristics. A docking study of the most active compound $\mathbf{5 b}$ was carried out to get insights into the Sirt-2 inhibitory mechanism and justify the in vitro results. The results revealed two possible binding patterns of $\mathbf{5 b}$ that could be used to rationalize its Sirt-2 inhibitory activity by either competition with acyl-Lys substrate or partially blocking co-factor $\mathrm{NAD}^{+} \mathrm{C}-$ pocket. These findings highlight the importance of Sirt- 2 as a promising anticancer target and open a new avenue to develop novel superior and selective Sirt-2 inhibitors.

\section{Experimental}

\subsection{Chemistry}

General details and crystallographic data (Table S1): see ESI $\dagger$ and Appendix A.

4.1.1. Synthesis of $(2 E, 4 E)$-5-(benzo[d] $[1,3]$ dioxol-5-yl) penta-2,4-dienoyl chloride (3). Compounds 2 and 3 were 
prepared according to our previous research work ${ }^{35}$ and the experimental details are recorded in Appendix A.

4.1.2. Synthesis of hydrazone derivatives $(4 a-h) \cdot{ }^{49-51}$ To a solution of carbonyl compounds $(2.5 \mathrm{mmol})$, hydrazine monohydrate $(158 \mu \mathrm{L}, 3.25 \mathrm{mmol})$ in THF solution was added and refluxed for $24 \mathrm{~h}$. Then the hydrazone solution was dried by $200 \mathrm{mg}$ anhydrous $\mathrm{Na}_{2} \mathrm{SO}_{4}$ for $0.5 \mathrm{~h}$ and then $5 \AA$ molecular sieves powder $(250 \mathrm{mg})$ for $5-6 \mathrm{~h}$. The obtained hydrazones $\mathbf{4 a - h}$ were utilized directly to the next step.

4.1.3. General procedure for synthesis of piperine-based hydrazone derivatives (5a-h). Compound 3 (191 mg, $1.1 \mathrm{mmol}$ ) was dissolved in $\mathrm{CH}_{2} \mathrm{Cl}_{2}(5 \mathrm{~mL})$ and was added dropwise into a mixture of the hydrazones $(\mathbf{4 a}-\mathbf{h}, 100 \mathrm{mg}, 1 \mathrm{mmol})$ in $\mathrm{CH}_{2} \mathrm{Cl}_{2}(5$ $\mathrm{mL}$ ) in ice bath. After addition of compound 3, the reaction mixture was stirred for $7 \mathrm{~h}$ at room temperature, and then the solvent was removed under reduced pressure. The crud product was treated with $\mathrm{Na}_{2} \mathrm{CO}_{3}$ solution, then extracted three times by ethyl acetate. The organic layer was dried over $\mathrm{Na}_{2} \mathrm{SO}_{4}$ and the solvent was evaporated under reduced pressure. The residue was purified by silica gel column chromatography $\left(\mathrm{CH}_{2} \mathrm{Cl}_{2}: \mathrm{MeOH}=\right.$ $20: 1)$ to give the corresponding compounds $\mathbf{5 a - h}(69.1-89.2 \%$ yields). Crystals were grown after slow evaporation of a mixture solution of methanol and $\mathrm{CH}_{2} \mathrm{Cl}_{2}$ (2:3) with the appropriate amount of $\mathbf{5 a}-\mathbf{f}$, then left open to the atmosphere at room temperature, producing yellow sheets and cubic crystals after 45 days.

4.1.3.1. (2E,4E)-5-(Benzo[d][1,3]dioxol-5-yl)- $N^{\prime}-((E, Z)-4-$ hydroxybenzylidene)penta-2,4-dienehydrazide (5a). Pale yellow solid, m.p. $12-127{ }^{\circ} \mathrm{C}$, yield: 83\%; IR: 3463, 3104 3050, 2890, 1660, 1600, 1500, 1448, 1400, 1384, 1260. ${ }^{1} \mathrm{H}$ NMR $(600 \mathrm{MHz}$, DMSO-d6) $\delta 11.40$ (s, 0.49H, NH), 11.20 (s, 0.46H, NH), 9.98 (d, $0.51 \mathrm{H}, \mathrm{OH}), 9.91(\mathrm{~d}, 0.46 \mathrm{H}, \mathrm{OH}), 8.12(\mathrm{~s}, 0.51 \mathrm{H}, 1 \mathrm{H}, \mathrm{CH}=\mathrm{N})$, $7.93(\mathrm{~s}, 0.46 \mathrm{H}, 1 \mathrm{H}, \mathrm{CH}=\mathrm{N}), 7.54(\mathrm{~d}, J=8.6 \mathrm{~Hz}, 2 \mathrm{H}), 7.41-7.26$ (m, 2H), 7.20-7.07 (m, 1H), $7.02(\mathrm{dd}, J=15.7,6.3 \mathrm{~Hz}, 1 \mathrm{H}), 6.99-$ $6.95(\mathrm{~m}, 1 \mathrm{H}), 6.93(\mathrm{dd}, J=8.0,4.3 \mathrm{~Hz}, 1 \mathrm{H}), 6.83(\mathrm{~d}, J=8.6 \mathrm{~Hz}$, $2 \mathrm{H}), 6.15(\mathrm{~d}, J=14.9 \mathrm{~Hz}, 1 \mathrm{H}), 6.06\left(\mathrm{~d}, J=2.8 \mathrm{~Hz}, 2 \mathrm{H},-\mathrm{OCH}_{2} \mathrm{O}-\right)$. ${ }^{13} \mathrm{C}$ NMR (150 MHz, DMSO-d6) $\delta$ 166.47, 161.91, 159.81, 159.57, $148.45,148.37,147.12$, 131.31, 131.25, 129.34, 129.21, 128.93, 128.79, 125.82, 123.33, 116.23, 116.04, 109.02, 106.23, 106.07, 101.79. $\mathrm{C}_{20} \mathrm{H}_{20} \mathrm{~N}_{2} \mathrm{O}_{5}$, crystal dimensions $0.12 \times 0.1 \times 0.1 \mathrm{~mm}^{3}$, $M_{\mathrm{r}}=368.38$, monoclinic, space group $P 2{ }_{1} / n$ (14) cell: $a=$ 10.9249(5), $b=6.5740(3), c=25.7341(11) \AA, \alpha=90^{\circ}, \beta=$ $94.790(3)^{\circ}, \gamma=90^{\circ}, V=1841.78(14) \AA^{3}, Z=4$, density (calculated) $=1.329 \mathrm{~g} \mathrm{~m}^{-3}, \mu=0.799 \mathrm{~mm}^{-1}, F(000)=776.0$, reflection collected/unique $=10352 / 3035$, refinement method $=$ fullmatrix least-squares on $F 2$, Final $R$ indices $[I>2 \operatorname{sigma}(I)]: R_{1}$ $=0.0925, \mathrm{w} R_{2}=0.2368, R$ indices (all data): $R_{1}=0.1011, \mathrm{w} R_{2}=$ 0.2530 , goodness of fit on $F^{2}=1.026$. CCDC 1984251 (Fig. 9A).

4.1.3.2. (2E,4E)-5-(Benzo[d][1,3]dioxol-5-yl)- $N^{\prime}-((E)-2,4-$ dihydroxybenzylidene)penta-2,4-dienehydrazide (5b). Yellow solid, m.p. $153-156{ }^{\circ} \mathrm{C}$, yield: 80\%; IR: 3432, 3300, 3030, 2902, 1650, 1602, 1515, 1439, 1367, 1252. ${ }^{1} \mathrm{H}$ NMR (600 MHz, DMSOd6) $\delta 11.64(\mathrm{~s}, 1 \mathrm{H}, \mathrm{NH}), 11.38(\mathrm{~s}, 1 \mathrm{H}, \mathrm{OH}), 9.95(\mathrm{~s}, 1 \mathrm{H}, \mathrm{OH}), 8.24$ $(\mathrm{d}, J=4.8 \mathrm{~Hz}, 1 \mathrm{H}, \mathrm{CH}=\mathrm{N}), 7.38-7.31(\mathrm{~m}, 1 \mathrm{H}), 7.29(\mathrm{~d}, J=7.8 \mathrm{~Hz}$, 2H), 7.07-6.96 (m, 3H), $6.93(\mathrm{t}, J=8.2 \mathrm{~Hz}, 1 \mathrm{H}), 6.37-6.28(\mathrm{~m}$, $2 \mathrm{H}), 6.14(\mathrm{~d}, J=14.9 \mathrm{~Hz}, 1 \mathrm{H}), 6.06\left(\mathrm{~s}, 2 \mathrm{H},-\mathrm{OCH}_{2} \mathrm{O}-\right) .{ }^{13} \mathrm{C} \mathrm{NMR}$ (151 MHz, DMSO-d6) $\delta 166.4,164.1,161.9,150.3,148.5,142.5$,
$141.5,140.9,140.1,136.0,131.2,126.2,125.9,125.6,123.9$, $123.6,121.9,117.6,114.9,113.2$, 111.1, 109.0, 106.4, 102.0. $\mathrm{C}_{20} \mathrm{H}_{20} \mathrm{~N}_{2} \mathrm{O}_{6}$, crystal dimensions $0.12 \times 0.1 \times 0.1 \mathrm{~mm}^{3}, M_{\mathrm{r}}=$ 384.38, monoclinic, space group $P 2_{1} / c(14)$ cell: $a=6.6192(6)$, $b=19.7039(17), c=14.2723(13) \AA, \alpha=90^{\circ}, \beta=99.079(5)^{\circ}, \gamma=$ $90^{\circ}, V=1841.78(14) \AA^{3}, Z=4$, density (calculated) $=$ $1.389 \mathrm{~g} \mathrm{~m}^{-3}, \mu=0.866 \mathrm{~mm}^{-1}, F(000)=808.0$, reflection collected/unique $=10609 / 2973$, refinement method $=$ fullmatrix least-squares on $F^{2}$, Final $R$ indices $[I>2 \operatorname{sigma}(I)]: R_{1}=$ $0.0461, \mathrm{w} R_{2}=0.1239, R$ indices (all data): $R_{1}=0.0507, \mathrm{w} R_{2}=$ 0.1332, goodness of fit on $F^{2}=1.074$. CCDC 1984253 (Fig. 9B).

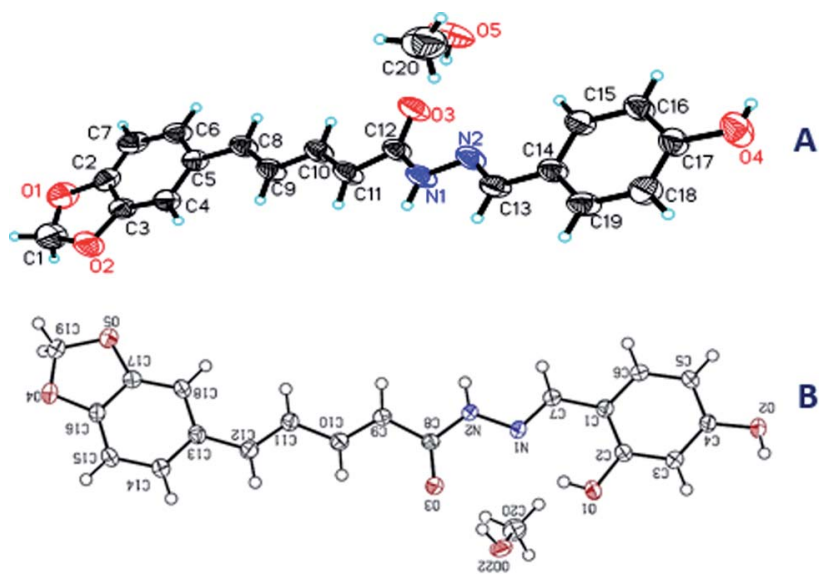

Fig. 9 The $X$-ray single crystal structures of $5 a(A)$ and $5 b(B)$.

4.1.3.3. (2E,4E)-5-(Benzo[d][1,3]dioxol-5-yl)- $N^{\prime}-((E, Z)-4-$ hydroxy-3-methoxybenzylidene)penta-2,4-dienehydrazide (5c). Pale yellow solid, m.p. $210-213{ }^{\circ} \mathrm{C}$, yield: 76.4\%; IR: 3401, 3231, 3029, 2909, 2831, 1624, 1606, 1507, 1445, 1375, 1337, $1258 .{ }^{1} \mathrm{H}$ NMR (600 MHz, DMSO-d $\left.d_{6}\right) \delta 11.44$ (s, 0.55H, NH), 11.25 (s, $0.43 \mathrm{H}, \mathrm{NH}), 9.54(\mathrm{~s}, 0.53 \mathrm{H}, \mathrm{OH}), 9.50(\mathrm{~s}, 0.39 \mathrm{H}, \mathrm{OH}), 8.13(\mathrm{~s}$, $0.51 \mathrm{H}, 1 \mathrm{H}, \mathrm{CH}=\mathrm{N}), 7.93(\mathrm{~s}, 0.40 \mathrm{H}, 1 \mathrm{H}, \mathrm{CH}=\mathrm{N}), 7.50-7.23(\mathrm{~m}$, $3 \mathrm{H}), 7.19-7.06(\mathrm{~m}, 2 \mathrm{H}), 7.03(\mathrm{dd}, J=10.3,7.8 \mathrm{~Hz}, 1 \mathrm{H}), 6.99(\mathrm{~s}$, $1 \mathrm{H}), 6.93(\mathrm{~d}, J=13.2 \mathrm{~Hz}, 1 \mathrm{H}), 6.85(\mathrm{~s}, 1 \mathrm{H}), 6.18(\mathrm{~d}, J=14.9 \mathrm{~Hz}$, $1 \mathrm{H}), 6.06$ (d, $\left.J=1.7 \mathrm{~Hz}, 2 \mathrm{H},-\mathrm{OCH}_{2} \mathrm{O}-\right), 3.85$ (d, $J=18.9 \mathrm{~Hz}, 3 \mathrm{H}$, $\left.\mathrm{OCH}_{3}\right) .{ }^{13} \mathrm{C}$ NMR (150 MHz, DMSO-d6) $\delta$ 166.46, 161.95, 149.39, $149.11,148.48,148.44,148.37,147.38$, 143.74, 142.86, 141.50, $139.63,139.35,131.25,126.26,126.22,125.68,123.41,123.01$, $122.51,121.41,120.34,116.06,115.89,110.25,109.47,108.94$, 106.16, 101.79, 56.18. $\mathrm{C}_{20} \mathrm{H}_{18} \mathrm{~N}_{2} \mathrm{O}_{5}$, crystal dimensions $0.12 \times$ $0.1 \times 0.1 \mathrm{~mm}^{3}, M_{\mathrm{r}}=366.36$, monoclinic, space group $P 2_{1} / c(14)$ cell: $a=18.1988(7), b=4.8105(2), c=22.1672(8) \AA, \alpha=90^{\circ}, \beta=$ 112.874(3) $)^{\circ}, \gamma=90^{\circ}, V=1788.03(13) \AA^{3}, Z=4$, density (calculated $)=1.361 \mathrm{~g} \mathrm{~m}^{-3}, \mu=0.822 \mathrm{~mm}^{-1}, F(000)=768.0$, reflection collected/unique $=14927 / 3069$, refinement method $=$ fullmatrix least-squares on $F^{2}$, final $R$ indices $[I>2 \operatorname{sigma}(I)]: R_{1}=$ $0.0490, \mathrm{w} R_{2}=0.1431, R$ indices (all data): $R_{1}=0.0687, \mathrm{w} R_{2}=$ 0.1575 , goodness of fit on $F^{2}=1.052$. CCDC 2009516 .

4.1.3.4. (2E,4E)-5-(Benzo[d][1,3]dioxol-5-yl)-N'-((E/Z)-4-

(dimethylamino)-benzylidene)penta-2,4-dienehydrazide (5d). Pale yellow solid, m.p. $203-207^{\circ} \mathrm{C}$, yield: 69.1\%; IR: 3136, 3053, 2932, 
2853, 1640, 1610, 1497, 1447, 1372, 1340, 1260. ${ }^{1} \mathrm{H}$ NMR (600 MHz, DMSO-d6) $\delta 11.31$ (s, 0.54H, NH), 11.12 (s, 0.42H, NH), $8.08(\mathrm{~s}, 0.56 \mathrm{H}, \mathrm{CH}), 7.93(\mathrm{~s}, 0.44 \mathrm{H}, \mathrm{CH}), 7.52(\mathrm{dd}, J=8.9,2.7 \mathrm{~Hz}$, $2 \mathrm{H}), 7.43-7.24(\mathrm{~m}, 2 \mathrm{H}), 7.22-6.89(\mathrm{~m}, 4 \mathrm{H}), 6.74(\mathrm{dd}, J=8.8$, $4.2 \mathrm{~Hz}, 2 \mathrm{H}), 6.15(\mathrm{~d}, J=14.9 \mathrm{~Hz}, 1 \mathrm{H}), 6.06(\mathrm{~d}, J=2.4 \mathrm{~Hz}, 2 \mathrm{H}$, $-\mathrm{OCH}_{2} \mathrm{O}-$ ), 2.97 (s, 6H, N($\left.\left(\mathrm{CH}_{3}\right)_{2}\right) \cdot{ }^{13} \mathrm{C} \mathrm{NMR}(150 \mathrm{MHz}, \mathrm{DMSO}-d 6)$ $\delta 166.26,151.92,151.75,148.44,148.39,148.33,147.63,141.22$, $131.33,131.29,128.93,128.79,128.52,128.38,123.42,122.91$, 122.14, 112.39, 112.13, 109.02, 108.87, 106.21, 106.06, 101.78, 40.40. $\mathrm{C}_{21} \mathrm{H}_{24.75} \mathrm{~N}_{3} \mathrm{O}_{4.42}$, crystal dimensions $0.12 \times 0.04 \times 0.03$ $\mathrm{mm}^{3}, M_{\mathrm{r}}=389.87$, monoclinic, space group $P 2_{1} / n$ (14) cell: $a=$ 13.6957(16), $b=6.3687(7), c=24.058(3) \AA, \alpha=90^{\circ}, \beta=$ 104.090(6) ${ }^{\circ}, \gamma=90^{\circ}, V=2035.3(4) \AA^{3}, Z=4$, density (calculated) $=1.272 \mathrm{~g} \mathrm{~m}^{-3}, \mu=0.740 \mathrm{~mm}^{-1}, F(000)=828.0$, reflection collected/unique $=9153 / 2692$, refinement method $=$ full-matrix least-squares on $F^{2}$, final $R$ indices $[I>2 \operatorname{sigma}(I)]: R_{1}=0.0706$, $\mathrm{w} R_{2}=0.1880, R$ indices (all data): $R_{1}=0.1081, \mathrm{w} R_{2}=0.2150$, goodness of fit on $F^{2}=1.029$. CCDC 1984254 .

4.1.3.5. (2E,4E)-5-(Benzo[d][1,3]dioxol-5-yl)- $N^{\prime}-((E)-4-$ (diethylamino)-2-hydroxy benzylidene)penta-2,4-dienehydrazide (5e). The spectroscopic analysis matched with those previously our work published ${ }^{35}$ and included in appendix A.

4.1.3.6. (2E,4E)-5-(Benzo[d][1,3]dioxol-5-yl)- $N^{\prime}-($ bis(4fluorophenyl)methylene)penta-2,4-dienehydrazide (5f). Deep yellow solid, m.p. $190-193{ }^{\circ} \mathrm{C}$, yield: $71.7 \%$; IR: 3276, 3052, 2989, 2895, 1650, 1623, 1595, 1486, 1384, 1339, 1255. ${ }^{1} \mathrm{H}$ NMR $(600 \mathrm{MHz}$, DMSO- $d 6) \delta 10.24(\mathrm{~s}, 0.59 \mathrm{H}, \mathrm{NH}), 9.61(\mathrm{~s}, 0.44 \mathrm{H}, \mathrm{NH}), 7.52(\mathrm{~d}, J=$ $2.9 \mathrm{~Hz}, 2 \mathrm{H}), 7.41(\mathrm{~s}, 2 \mathrm{H}), 7.38(\mathrm{~d}, J=8.4 \mathrm{~Hz}, 2 \mathrm{H}), 7.31(\mathrm{~s}, 1 \mathrm{H}), 7.24$ $(\mathrm{s}, 3 \mathrm{H}), 6.92(\mathrm{t}, J=4.6 \mathrm{~Hz}, 4 \mathrm{H}), 6.36(\mathrm{~d}, J=14.7 \mathrm{~Hz}, 1 \mathrm{H}), 6.05(\mathrm{~s}, 2 \mathrm{H}$, $\left.-\mathrm{OCH}_{2} \mathrm{O}-\right) .{ }^{13} \mathrm{C}$ NMR (151 MHz, DMSO- $\left.d 6\right) \delta 164.02,162.39,148.44$, $143.81,141.82$, 139.57, 131.69, 131.17, 129.97, 126.24, 125.51, 123.41, 117.00, 115.92, 108.98, 106.16, 101.81. ${ }^{19} \mathrm{~F}$ NMR $(565 \mathrm{MHz}$, DMSO-d6) $\delta-106.46 . \mathrm{C}_{25} \mathrm{H}_{18} \mathrm{~F}_{2} \mathrm{~N}_{2} \mathrm{O}_{3}$, crystal dimensions $0.20 \times$ $0.12 \times 0.10 \mathrm{~mm}^{3}, M_{\mathrm{r}}=432.41$, monoclinic, space group $P 2_{1} / n$ (14)

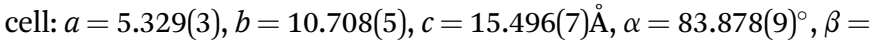
$87.608(9)^{\circ}, \gamma=82.240(9)^{\circ}, V=870.8(7) \AA^{3}, Z=4$, density (calculated $)=1.649 \mathrm{~g} \mathrm{~m}^{-3}, F(000)=448$, reflection collected/unique $=$ $6085 / 3045$, refinement method $=$ full-matrix least-squares on $F^{2}$, final $R$ indices $[I>2 \operatorname{sigma}(I)]: R_{1}=0.0623, \mathrm{w} R_{2}=0.1690, R$ indices (all data): $R_{1}=0.0965, \mathrm{w} R_{2}=0.1941$, goodness of fit on $F^{2}=1.029$. CCDC 1984255.

4.1.3.7. (2E,4E)-5-(Benzo[d][1,3]dioxol-5-yl)- $N^{\prime}-((E)-3,5$-di-tertbutyl-2-hydroxy-benzylidene)penta-2,4-dienehydrazide (5g). Deep yellow solid, m.p. $208-211^{\circ} \mathrm{C}$, yield: $72.3 \%$; IR: 3449, 3360, 3050, 2957, 2820, 1663, 1615, 1594, 1445, 1385, 1362, 1254. ${ }^{1} \mathrm{H}$ NMR (600 MHz, DMSO-d6) $\delta 12.19(\mathrm{~s}, 1 \mathrm{H}, \mathrm{NH}), 11.94(\mathrm{~s}, 1 \mathrm{H}, \mathrm{OH}), 8.36$ $(\mathrm{s}, 1 \mathrm{H}, \mathrm{CH}=\mathrm{N}), 7.40(\mathrm{dd}, J=15.0,9.7 \mathrm{~Hz}, 1 \mathrm{H}), 7.30(\mathrm{~s}, 2 \mathrm{H}), 7.24$ $(\mathrm{d}, J=2.3 \mathrm{~Hz}, 1 \mathrm{H}), 7.03(\mathrm{dd}, J=12.9,3.2 \mathrm{~Hz}, 3 \mathrm{H}), 6.94(\mathrm{~s}, 1 \mathrm{H})$, 6.19 (d, $J=14.9 \mathrm{~Hz}, 1 \mathrm{H}), 6.06\left(\mathrm{~s}, 2 \mathrm{H},-\mathrm{OCH}_{2} \mathrm{O}-\right), 1.41(\mathrm{~s}, 9 \mathrm{H}$, $\left.3 \mathrm{CH}_{3}\right), 1.26\left(\mathrm{~s}, 9 \mathrm{H}, 3 \mathrm{CH}_{3}\right) \cdot{ }^{13} \mathrm{C}$ NMR (151 MHz, DMSO-d6) $\delta 161.93,155.08,150.34,148.51,148.46,142.49,140.88,140.08$, $136.04,131.15,126.20,125.94,125.55,123.60,121.85,117.55$, 108.98, 106.20, 101.82, 35.11, 34.36, 31.77, 29.76.

4.1.3.8. (2E,4E)-5-(Benzo[d][1,3]dioxol-5-yl)- $N^{\prime}-((E)-1-(4-$ bromophenyl)ethylidene)penta-2,4-dienehydrazide (5h). Deep yellow solid, m.p. $188-192{ }^{\circ} \mathrm{C}$, yield: 69.1\%; IR: 3285, 3061, 2941, 2811, 2779, 1644, 1607, 1539, 1497, 1447, 1370, 1256. ${ }^{1} \mathrm{H}$ NMR
(600 MHz, DMSO-d6) $\delta 10.60(\mathrm{~s}, 1 \mathrm{H}, \mathrm{OH}), 7.77$ (d, $J=7.6 \mathrm{~Hz}$, $2 \mathrm{H}), 7.62(\mathrm{~d}, J=8.5 \mathrm{~Hz}, 2 \mathrm{H}), 7.38(\mathrm{dd}, J=27.5,13.6 \mathrm{~Hz}, 2 \mathrm{H}), 7.14$ $(\mathrm{d}, J=14.1 \mathrm{~Hz}, 1 \mathrm{H}), 7.01(\mathrm{dd}, J=29.7,6.8 \mathrm{~Hz}, 2 \mathrm{H}), 6.93$ (d, $J=$ $8.0 \mathrm{~Hz}, 1 \mathrm{H}), 6.48$ (d, $J=14.9 \mathrm{~Hz}, 1 \mathrm{H}), 6.06$ (s, 2H, $\left.-\mathrm{OCH}_{2} \mathrm{O}-\right), 2.28$ $(\mathrm{d}, J=16.7 \mathrm{~Hz}, 3 \mathrm{H}) .{ }^{13} \mathrm{C}$ NMR (151 MHz, DMSO-d6) $\delta$ 166.56, 148.46, 146.69, 143.03, 141.61, 139.65, 139.41, 131.24, 129.11, $128.73,127.39,126.26,125.68,123.44,122.94,120.27,114.77$, 108.95, 106.16, 101.79, 28.41.

\subsection{Biology}

4.2.1. Screening of cytotoxic activity. The methodology of the NCI anticancer screening has been described in detail elsewhere (https://dtp.cancer.gov/). ${ }^{52}$

4.2.2. Sirtuin inhibitory assay. Sirt- 1 and Sirt- 2 inhibitory assay was performed to evaluate the inhibitory potency of $\mathbf{5 a}-\mathbf{h}$ against Sirt-1 and Sirt-2. ${ }^{53}$ See ESI. $\dagger$

4.2.2.1. Cell apoptosis assay. Apoptosis was determined by flow cytometry based on the Annexin-V-fluoresce in isothiocyanate (FITC) and propidium iodide (PI) staining kit (BD Pharmingen, San Diego, USA). ${ }^{54,55}$ See ESI. $\dagger$

\section{Conflicts of interest}

The authors declare no competing financial interest.

\section{Acknowledgements}

This work was supported by the National Key Research and Development Program of China (2017YFE0113900) and Huazhong Agriculture University, Talent Young Scientist Program (Grant No. 42000481-7).

\section{References}

1 B. G. M. Youssif, M. H. Abdelrahman, A. H. Abdelazeem, M. A. abdelgawad, H. M. Ibrahim, O. I. A. Salem, M. F. A. Mohamed and L. Treamblu, Eur. J. Med. Chem., 2018, 146, 260-273.

2 A. H. Abdelazeem, M. T. El-Saadi, E. Gaber, B. G. M. Youssif and H. A. Omar, Bioorg. Chem., 2017, 75, 127-138.

3 M. S. Abdelbaset, G. E. A. Abuo-Rahma, M. H. Abdelrahman, M. Ramadan, B. G. M. Youssif, S. N. A. Bukhari and M. F. A. Mohamed, Bioorg. Chem., 2018, 80, 151-163.

4 J. Hu and H. Jing, Future Med. Chem., 2014, 6, 945-966.

5 M. Mottamal, S. Zheng and T. Huang, Molecules, 2015, 20, 3898-3941.

6 X. Ye, M. Li, T. Hou, T. Gao and W. G. Zhu, Oncotarget, 2017, 8, 1845-1859.

7 S. M. Jeong, Mol. Cells, 2015, 38, 750-758.

8 X. Wu, N. Cao and M. Fenech, DNA Cell Biol., 2016, 35, 542575.

9 V. L. Bosch-Presegu_e, FEBS J., 2015, 282, 1745-1767.

10 S. A. Bedalov and S. Chowdhury, Methods Enzymol., 2016, 574, 183-211.

11 P. Bheda, H. Jing and C. Wolberger, Rev. Biochem., 2016, 85, 405-429. 
12 E. Therrien, G. Larouche, N. Nguyen, J. Rahil, A. M. Lemieux, Z. Li, J. J. W. T. P. Yan, A. J. Landry and S. Lefebvre, Bioorg. Med. Chem. Lett., 2015, 25, 2514-2518.

13 N. Garmpis, C. Damaskos, A. Garmpi, D. Dimitroulis, E. Spartalis, G. A. Margonis, D. Schizas, I. Deskou, C. Doula and E. Magkouti, Anticancer Res., 2017, 37, 53555362.

14 Y. L. Wang, H. Chen, Y. Q. Zhan, R. H. Yin, C. Y. Li, C. H. Ge and M. Yu, Cell Cycle, 2016, 15, 2202-2215.

15 T. Wang, Z. Xu, Y. Lu, J. Shi, W. Liu, C. Zhang, Z. Jiang and B. Qi, Curr. Top. Med. Chem., 2019, 19, 1051-1058.

16 Y. Li, M. Zhang, R. G. Dorfman, Y. Pan, D. Tang, L. Xu, Z. Zhao, Q. Zhou, L. Zhou and Y. Wang, Neoplasia, 2018, 20, 745-756.

17 T. Eckschlager, J. Plch and M. Stiborova, Int. J. Mol. Sci., 2017, 18, 1-25.

18 Y. Huang, S. Zhao, Z. Tang, D. Zhou, Q. Li, Y. Zhou, L. Yin, Y. Wang, Y. Pan, T. Dorfman and R. G. Ling, Transl. Oncol., 2017, 10, 917-927.

19 S. Kaladhar and D. S. Kant, Metabolism, 2017, 4, 162-185.

20 N. George and J. Ahmad, Cancer Res., 2016, 76, 2500-2506.

21 C. K. Singh, G. Chhabra, M. A. Ndiaye, L. M. Garcia-Peterson and N. J. Mack, Antioxid. Redox Signaling, 2018, 28, 643-661.

22 P. Umadevi, K. Deepti and D. V. R. Venugopal, Med. Chem. Res., 2013, 22, 5466-5471.

23 Y. Deng, S. Sriwiriyajan, A. Tedasen, P. Hiransai and P. Graidist, J. Ethnopharmacol., 2016, 188, 87-95.

24 L. Katz and R. H. Baltz, J. Ind. Microbiol. Biotechnol., 2016, 43, 155-176.

25 D. J. Newman, G. M. Cragg and K. M. Snader, J. Nat. Prod., 2003, 66, 1022-1037.

26 Y. Ali, M. S. Alam, H. Hamid, A. Husain, S. Bano, A. Dhulap, C. Kharbanda, S. Nazreen and S. Haider, Eur. J. Med. Chem., 2015, 92, 490-500.

27 R. C. Conaway, C. S. Brower, J. W. Conaway and H. D. Ulrich, Annu. Rev. Cell Dev. Biol., 1999, 9, 107-112.

28 J. C. Milne, P. D. Lambert, S. Schenk, D. P. Carney, J. J. Smith, D. J. Gagne, L. Jin, O. Boss, R. B. Perni, C. B. Vu, J. E. Bemis, R. Xie, J. S. Disch, P. Y. Ng, J. J. Nunes, A. V. Lynch, H. Yang, H. Galonek, K. Israelian, W. Choy, A. Iffland, S. Lavu, O. Medvedik, D. A. Sinclair, J. M. Olefsky, M. R. Jirousek, P. J. Elliott and C. H. Westphal, Nature, 2007, 450, 712-716.

29 J. Trapp, A. Jochum, R. Meier, L. Saunders, B. Marshall, C. Kunick, E. Verdin, P. Goekjian, W. Sippl and M. Jung, J. Med. Chem., 2006, 49, 7307-7316.

30 M. Gertz, G. T. T. Nguyen, F. Fischer, B. Suenkel, C. Schlicker, B. Fränzel, J. Tomaschewski, F. Aladini, C. Becker, D. Wolters and C. Steegborn, PLoS One, 2012, 7, 1-12.

31 M. T. Borra, B. C. Smith and J. M. Denu, J. Biol. Chem., 2005, 280, 17187-17195.

32 J. J. Johnson, M. Nihal, I. A. Siddiqui, C. O. Scarlett, H. H. Bailey, H. Mukhtar and N. Ahmad, Mol. Nutr. Food Res., 2011, 55, 1169-1176.

33 B. Schmidt, C. Ferreira, C. L. A. Passos, J. L. Silva and E. Fialho, Int. J. Mol. Sci., 2020, 21(15), 5244.

34 A. H. Tantawy, K. A. Soliman and H. M. Abd El-Lateef, J. Cleaner Prod., 2019, 119510.
35 A. H. Tantawy, S. M. Farag, L. Hegazy, H. Jiang and M. Q. Wang, Bioorg. Chem., 2019, 103464.

36 H. Qu, X. Yu, X. Zhi, M. Lv and H. Xu, Bioorg. Med. Chem. Lett., 2013, 23, 5552-5557.

37 R. Le Goff, M. Sanselme, M. Lawson, A. Daïch and S. Comesse, Eur. J. Org. Chem., 2015, 7244-7248.

38 R. Le Goff, A. Martel, M. Sanselme, M. Lawson and A. Dal, Chem.-Eur. J., 2015, 21, 2966-2979.

39 T. Yang, X. Chen, H. X. Jin, G. Sethi and M. L. Go, Eur. J. Med. Chem., 2015, 92, 145-155.

40 M. A. Spackman and J. J. McKinnon, CrystEngComm, 2002, 4, 378-392.

41 M. A. Spackman and D. Jayatilaka, CrystEngComm, 2009, 11, 19-32.

42 J. J. McKinnon, M. A. Spackman and A. S. Mitchell, Novel tools for visualizing and exploring intermolecular interactions in molecular crystals, 2004, vol. 60.

43 B. G. M. Youssif, M. H. Abdelrahman, A. H. Abdelazeem, M. A. Abdelgawad, H. M. Ibrahim, O. I. A. Salem and M. F. A. Mohamed, Eur. J. Med. Chem., 2018, 146, 260-273.

44 A. H. Abdelazeem, A. G. Safi El-Din, M. M. Abdel-Fattah, N. H. Amin, S. M. El-Moghazy and M. T. El-Saadi, Eur. J. Med. Chem., 2020, 205, 112662.

45 M. H. Abdelrahman, B. G. M. Youssif, M. A. abdelgawad, A. H. Abdelazeem, H. M. Ibrahim, A. E. G. A. Moustafa, L. Treamblu and S. N. A. Bukhari, Eur. J. Med. Chem., 2017, 127, 972-985.

46 G. F. Zha, H. L. Qin, B. G. M. Youssif, M. W. Amjad, M. A. G. Raja, A. H. Abdelazeem and S. N. A. Bukhari, Eur. J. Med. Chem., 2017, 135, 34-48.

47 T. Rumpf, M. Schiedel, B. Karaman, C. Roessler, B. J. North, A. Lehotzky, J. Oláh, K. I. Ladwein, K. Schmidtkunz, M. Gajer, M. Pannek, C. Steegborn, D. A. Sinclair, S. Gerhardt, J. Ovádi, M. Schutkowski, W. Sippl, O. Einsle and M. Jung, Nat. Commun., 2015, 6, 6263.

48 S. Swyter, M. Schiedel, D. Monaldi, S. Szunyogh, A. Lehotzky, T. Rumpf, J. Ovádi, W. Sippl and M. Jung, Philos. Trans. $R$. Soc., B, 2018, 373, 20170083.

49 H. Zeng, Z. Luo, X. Han and C. J. Li, Org. Lett., 2019, 21, 59485951.

50 D. Zhu, L. Lv, C. Li, S. Ung, J. Gao and C. Li, Angew. Chem., Int. Ed., 2018, 57, 16520-16524.

51 J. Poh, D. N. Tran, C. Battilocchio, J. M. Hawkins and S. V Ley, Angew. Chem., Int. Ed., 2015, 54, 7920-7923.

52 H. A. M. El-Sherief, B. G. M. Youssif, S. N. A. Bukhari, M. Abdel-Aziz and H. M. Abdel-Rahman, Bioorg. Chem., 2018, 76, 314-325.

53 D. Rotili, D. Tarantino, V. Carafa, E. Lara, S. Meade, G. Botta, A. Nebbioso, M. Jung, A. G. Kazantsev, M. Esteller, M. F. Fraga, L. Altucci and A. Mai, ChemMedChem, 2010, 674-677.

54 B. G. M. Youssif, A. M. Mohamed, E. Eldin, A. Osman, O. F. Abou-ghadir, D. H. Elnaggar, M. H. Abdelrahman, L. Treamblu and H. A. M. Gomaa, Eur. J. Med. Chem., 2019, 177, 1-11.

55 H. A. Abou-zied, B. G. M. Youssif, M. F. A. Mohamed and A. M. Hayallah, Bioorg. Chem., 2019, 89, 102997. 